\title{
Inverse relationship between body mass index and mortality in older nursing home residents: a meta-analysis of 19,538 elderly subjects
}

N Veronese, E Cereda, M Solmi, S.A. Fowler, E Manzato, S Maggi, P Manu, E Abe, K Hayashi, J.P. Allard, B.M. Arendt, A Beck, M Chan, Y.J.P. Audrey, W-Y Lin, H-S Hsu, C-C Lin, R Diekmann, S Kimyagarov, M Miller, I.D. Cameron, K.H. Pitkälä, J Lee, J Woo, K Nakamura, D Smiley, G Umpierrez, M Rondanelli, Märtha Sund-Levander, L Valentini, K Schindler, J Törmä, S Volpato, G Zuliani, M Wong, K Lok, J.M. Kane, G Sergi and C.U. Correll

\section{Linköping University Post Print}

\section{Tweet}

N.B.: When citing this work, cite the original article.

Original Publication:

N Veronese, E Cereda, M Solmi, S.A. Fowler, E Manzato, S Maggi, P Manu, E Abe, K Hayashi, J.P. Allard, B.M. Arendt, A Beck, M Chan, Y.J.P. Audrey, W-Y Lin, H-S Hsu, C-C Lin, R Diekmann, S Kimyagarov, M Miller, I.D. Cameron, K.H. Pitkälä, J Lee, J Woo, K Nakamura, D Smiley, G Umpierrez, M Rondanelli, Märtha Sund-Levander, L Valentini, K Schindler, J Törmä, S Volpato, G Zuliani, M Wong, K Lok, J.M. Kane, G Sergi and C.U. Correll, Inverse relationship between body mass index and mortality in older nursing home residents: a meta-analysis of 19,538 elderly subjects, 2015, Obesity Reviews.

http://dx.doi.org/10.1111/obr.12309

Copyright: Wiley: 12 months

http://eu.wiley.com/WileyCDA/

Postprint available at: Linköping University Electronic Press

http://urn.kb.se/resolve?urn=urn:nbn:se:liu:diva-121461 


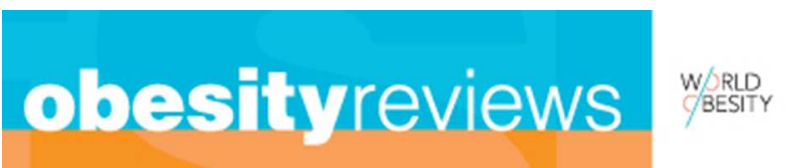

\section{Inverse Relationship Between Body Mass Index and Mortality in Older Nursing-Home Residents: A Meta-analysis of 19,538 Elderly Subjects}

\begin{tabular}{|c|c|}
\hline Journal: & Obesity Reviews \\
\hline Manuscript ID: & OBR-04-15-2217.R2 \\
\hline Manuscript Type: & Review \\
\hline Date Submitted by the Author: & $\mathrm{n} / \mathrm{a}$ \\
\hline Complete List of Authors: & $\begin{array}{l}\text { Veronese, Nicola; University of Padova, Department of Medicine } \\
\text { Cereda, Emanuele } \\
\text { Solmi, Marco } \\
\text { Fowler, Susan } \\
\text { Manzato, Enzo } \\
\text { Maggi, Stefania } \\
\text { Manu, Peter } \\
\text { Abe, Eiko } \\
\text { Hayashi, Kunihiko } \\
\text { Allard, Johanne } \\
\text { Arendt, Bianca } \\
\text { Beck, Anne } \\
\text { Chan, Mark } \\
\text { Audrey, Yeo Jing Ping } \\
\text { Lin, Wen-Yuan } \\
\text { Hsu, Hua-Shui } \\
\text { Lin, Cheng-Chieh } \\
\text { Diekmann, Rebecca } \\
\text { Kimyagarov, Simcha } \\
\text { Miller, Michelle } \\
\text { Cameron, Ian } \\
\text { Pitkala, Kaisu } \\
\text { Lee, Jenny } \\
\text { Woo, Jean; The Chinese University of Hong Kong, School of Public Health } \\
\text { Nakamura, Kazutoshi } \\
\text { Smiley, Dawn } \\
\text { Umpierrez, Guillermo } \\
\text { Rondanelli, Mariangela } \\
\text { Sund-Levander, Martha } \\
\text { Valentini, Luzia } \\
\text { Schindler, Karin } \\
\text { Torma, Johanna } \\
\text { Volpato, Stefano } \\
\text { Zuliani, Giovanni } \\
\text { Wong, Moses } \\
\text { Lok, Kris }\end{array}$ \\
\hline
\end{tabular}




\section{Page 1 of 88}

Obesity Reviews

1
2
3
4
5
6
7
8
9
10
11
12
13
14
15
16
17
18
19
20
21
22
23
24
25
26
27
28
29
30
31
32
33
34
35
36
37
38
39
40
41
42
43
44
45
46
47
48
49
50
51
52
53
54
55
56
57
58
60

\begin{tabular}{|l|l|}
\hline & $\begin{array}{l}\text { Kane, John } \\
\text { Sergi, Giuseppe } \\
\text { Correll, Christoph; The Zucker Hillside Hospital, Psychiatry Research }\end{array}$ \\
\hline Keywords: & mortality, elderly, nursing-home, body mass index \\
\hline
\end{tabular}

SCHOLARONE ${ }^{m}$

Manuscripts 
June, $30^{\text {th }} 2015$

To: David York, M.D.

Editor of Bone

RE: Manuscript reference OBR-2217

Dear Dr. York:

We thank you and the reviewers for evaluating our manuscript, entitled "Inverse Relationship Between Body Mass Index and Mortality in Older Nursing-Home Residents: A Meta-analysis of 19,538 Elderly Subjects" and appreciate the opportunity to submit a revised version.

We have made a point-by-point response to the Editor's comments and revised the manuscript accordingly.

We would like to acknowledge the helpful assessment of our manuscript provided by the Editor. Their insight has resulted in an improvement in the clarity and accuracy of our manuscript. We hope we have adequately addressed the concerns raised by the Editor in our response and in the changes made in the revised manuscript. Thank you for reconsidering our manuscript for publication in Obesity Reviews.

Sincerely,

Nicola Veronese, MD and Christoph U. Correll, MD 
1. Figures must be submitted as eps or tif format not ppt.

R: sorry for this mistake. All figures are now made in tif format.

2.References with 7 or more authors are reduced to first 3 authors et al (Ref 29)

R: thank you for your observation. We have corrected the references with more than 7 authors according to the guidelines of the Journal.

3. Supplemental data must be in the same format as the manuscript. One PDF file is not acceptable. Figures must be separate files in eps or tif format as for the main document.

R: sorry for this mistake. All figures are now made in tif format. 


\title{
Inverse Relationship Between Body Mass Index and Mortality in Older Nursing-Home Residents: A Meta-analysis of 19,538 Elderly Subjects
}

Running title: BMI and mortality in nursing home

\begin{abstract}
Nicola Veronese ${ }^{1}$, Emanuele Cereda $^{2}$, Marco Solmi $^{3}$, Susan A. Fowler ${ }^{4}$, Enzo Manzato ${ }^{1,5}$, Stefania Maggi ${ }^{5}$, Peter Manu ${ }^{6-9}$, Eiko Abe ${ }^{10}$, Kunihiko Hayashi ${ }^{10}$, Johane Allard ${ }^{11,12}$, Bianca Arendt ${ }^{11}$, Anne Marie Beck ${ }^{13}$, Mark Chan ${ }^{14}$, Yeo Jing Ping Audrey ${ }^{14}$, Wen-Yuan Lin ${ }^{15}$, Hua-Shui Hsu ${ }^{15}$, Cheng-Chieh Lin ${ }^{15}$, Rebecca Diekmann $^{16}$, Simca Kimyagarov ${ }^{17}$, Michelle Miller ${ }^{18}$, Ian Cameron ${ }^{19}$, Kaisu H. Pitkälä ${ }^{20}$, Jenny Lee ${ }^{21}$, Jean Woo $^{21}$, Kazutoshi Nakamura ${ }^{22}$, Dawn Smiley ${ }^{23}$, Guillermo Umpierrez ${ }^{23}$, Mariangela Rondanelli ${ }^{24}$, Martha Sund-Levander ${ }^{25}$, Luzia Valentini ${ }^{26}$, Karin Schindler ${ }^{27}$, Johanna Törmä ${ }^{28}$, Stefano Volpato ${ }^{29}$, Giovanni Zuliani $^{29}$, Moses Wong ${ }^{30}$, Kris Lok ${ }^{30}$, John M. Kane ${ }^{6-9}$, Giuseppe Sergi ${ }^{1}$, Christoph U. Correll ${ }^{6-9}$
\end{abstract}

\section{Affiliations:}

${ }^{1}$ Department of Medicine- DIMED, Geriatrics Section, University of Padova, Italy.

${ }^{2}$ Nutrition and Dietetics Service, Fondazione IRCCS Policlinico San Matteo, Pavia, Italy.

${ }^{3}$ Department of Neurosciences, University of Padova, Padova, Italy.

${ }^{4}$ Becker Medical Library, Washington University in St. Louis, MO, USA.

${ }^{5}$ National Research Council, Institute of Neuroscience, Padova, Italy.

${ }^{6}$ The Zucker Hillside Hospital, Psychiatry Research, North Shore - Long Island Jewish Health System, Glen Oaks, New York, USA.

${ }^{7}$ Hofstra North Shore LIJ School of Medicine, Hempstead, New York, USA.

${ }^{8}$ The Feinstein Institute for Medical Research, Manhasset, New York, USA.

${ }^{9}$ Albert Einstein College of Medicine, Bronx, New York, USA.

${ }^{10}$ Gunma University Graduate School of Health Sciences, Maebashi, Gunma, Japan.

${ }^{11}$ Toronto General Hospital, University Health Network, Toronto, Canada.

${ }^{12}$ Department of Medicine, University of Toronto, Toronto, Canada.

${ }^{13}$ Research Unit for Nutrition (EFFECT), Herlev University Hospital, Herlev, Denmark.

${ }^{14}$ Department of Geriatric Medicine, Tan Tock Seng Hospital, Jalan Tan Tock Seng, Singapore. 
${ }^{15}$ Department of Family Medicine, China Medical University Hospital, Taichung, Taiwan and School of Medicine, China Medical University, Taichung, Taiwan.

${ }^{16}$ Institute for Biomedicine of Aging, Friedrich-Alexander-Universität Erlangen-Nürnberg, Nürnberg, Germany.

${ }^{17}$ The Gilad Geriatric Center, Ramat-Gan, Israel.

${ }^{18}$ Nutrition and Dietetics, Flinders University, Adelaide, Australia.

${ }^{19}$ Rehabilitation Studies Unit, University of Sydney, Australia.

${ }^{20}$ Unit of Primary Health Care, Helsinki University Central Hospital, Department of General Practice, Helsinki, Finland.

${ }^{21}$ The S. H. Ho Center for Gerontology and Geriatrics, The Chinese University of Hong Kong, Hong Kong SAR, China; Department of Medicine and Therapeutics, The Chinese University of Hong Kong, Hong Kong SAR, China.

${ }^{22}$ Division of Preventive Medicine, Niigata University Graduate School of Medical and Dental Sciences, Niigata, Japan.

${ }^{23}$ Division of Endocrinology and Metabolism, Department of Medicine, Emory University School of Medicine, Atlanta, GA, USA.

${ }^{24}$ Department of Public Health, Experimental and Forensic Medicine, Section of Human Nutrition, Endocrinology and Nutrition Unit, University of Pavia, Pavia, Italy.

${ }^{25}$ Faculty of Health Sciences, University of Linköping, Linköping, Sweden.

${ }^{26}$ Section of Dietetics, Department of Agriculture and Food Sciences, University of Applied Sciences, Neubrandenburg, Germany.

${ }^{27}$ Division of Endocrinology and Metabolism, Department of Internal Medicine III, Medical University Vienna, Vienna, Austria.

${ }^{28}$ Department of Public Health and Caring Sciences, Clinical Nutrition and Metabolism, Uppsala Science Park, Uppsala, Sweden.

${ }^{29}$ Department of Medical Sciences, University of Ferrara, Ferrara, Italy.

${ }^{30}$ Department of Medicine \& Therapeutics, The Chinese University of Hong Kong. 


\section{Correspondence to:}

Christoph U. Correll, MD, Department of Psychiatry, The Zucker Hillside Hospital, 75-59 $263^{\text {rd }}$ Street, Glen

Oaks, NY 11004. Email: ccorrell@lij.edu, phone: (718) 470-4812, fax (718) 343-1659

Key Words: Mortality; Elderly; Nursing-Home; Body Mass Index.

\section{Conflict of interest: none.}




\begin{abstract}
Body mass index (BMI) and mortality in old adults from general population have been related in a U-shaped or J-shaped curve. However, limited information is available for elderly nursing-home populations, particularly about specific cause death. A systematic PubMed/EMBASE/CINAHL/SCOPUS search until 05/31/2014 without language restrictions was made. As no published study reported mortality in standard BMI groups $(<18.5,18.5-24.9,25-29.9, \geq 30)$, the most adjusted hazard ratios (HRs) according to a predefined list of covariates were obtained from authors and pooled by random-effect model across each BMI category. Out of 342 hits, 20 studies including 19,538 older residents with 5,223 deaths and during a median of 2 years of follow-up were meta-analyzed. Compared to normal weight, all-cause mortality HRs were 1.41 $(95 \% \mathrm{CI}=1.26-1.58)$ for underweight, $0.85(95 \% \mathrm{CI}=0.73-0.99)$ for overweight and $0.74(95 \% \mathrm{CI}=0.57-0.96)$ for obesity. Underweight was a risk factor for higher mortality due to infections [HR=1.65 (95\% $\mathrm{CI}=1.13$ 2.40)]. RR results corroborated primary HR results, with additionally lower infection-related mortality in overweight and obese than normal weight individuals.Like in the general population, underweight is a risk factor for mortality in old nursing-home residents. However, uniquely, not only overweight but also obesity is protective, which has relevant nutritional goal implications in this population/setting.
\end{abstract}




\section{INTRODUCTION}

Body mass index (BMI) is the most common method to assess nutritional status in population studies.

In the adult general population, BMI was found to be associated with mortality in a U-shaped curve relationship in some studies ${ }^{1,2}$ while others have suggested a J-shaped relationship. ${ }^{3,4}$ In both cases, the evidence is that risk of death is increased in those having low or high BMI.

Older people are a continuously increasing population in developed/developing countries. Aging is substantially characterized by changes in body composition and muscle loss due to relevant changes of food intake and physical activity, multiple chronic diseases, hormonal changes and proneness to acute diseases and body weight loss. ${ }^{5,6}$ Several studies in community-dwelling old adults demonstrated that overweight and mild obesity decrease mortality compared to normal or underweight status. ${ }^{7-12}$ These contrasting findings compared to middle-aged populations were further confirmed by studies conducted in acute and sub-acute healthcare settings and in patients suffering from high-mortality risk diseases. ${ }^{13-19}$

The protective effect of overweight - but not of obesity - in adults aged $\geq 65$ years has also recently been reported in a large meta-analysis of 97 studies. $^{20}$ However, no prior review or meta-analysis focused on nursing-home residents, and the relationship between BMI and mortality in this population is less clear. As the number of older people and those suffering from end-stage dementia and other non-communicable diseases, nutritional problems, sarcopenia, and low functioning continues to rise, the population of institutionalized old people will very likely too. ${ }^{21,22}$ Furthermore, the high prevalence of chronic illness in nursing-home residents complicates the applicability of mortality risk associated with BMI from general population.

We conducted a meta-analysis of longitudinal studies in nursing-home residents to assess the role of overweight and obesity for all-cause and specific-cause mortality in this particular setting and population. Based on prior data in community dwelling populations and the higher prevalence of chronic disorders in nursing-home residents that are associated with weight loss and wasting, which in turn can lead to frailty and decreased immunity, we hypothesized that overweight and obesity may be protective of all-cause mortality in this old, high-risk mortality population. 


\section{METHODS}

This systematic review was conducted following the MOOSE guidelines, ${ }^{23}$ and data reporting was performed in agreement with PRISMA statement. ${ }^{24}$

\section{Data sources and literature search strategy}

We created search strategies for the concepts of "nursing-home", "mortality", and "body weight", including "underweight", "body mass index", and "overweight", using a combination of standardized terms and keywords harvested from indices, thesauri, and on-topic articles. To exclude randomized controlled trials and clinical studies, we created a filter, using only standardized terminology tagged as "publication type" to not over-reduce the search recall. We searched Medline via PubMed, Embase, Scopus, CINAHL, Applied Social Sciences Index and Abstracts, and Social Work Abstracts from database inception until 05/31/2014 (see Table S1 for search terms). We further conducted a manual search of reference lists of relevant articles. Conference abstracts were also considered. All articles were reviewed for inclusion by two independent reviewers (NV and MS). Any discrepancies were resolved by consensus.

\section{Study selection \\ Inclusion criteria were: 1) prospective, observational cohort study; 2) study population's mean age $\geq 65$ years, 3) nursing-home residents; and 4) assessment of BMI and all-cause and/or specific-cause mortality. Exclusion criteria were: 1) non-nursing home setting, including geriatric hospital units; 2) nursing-home residents admitted for a specific medical condition (e.g., after hip fracture) or being restricted to one disorder (e.g., dementia); and 3) intervention studies.}

\section{Data extraction}

To be included in the quantitative analyses, we required data on either risk values (hazard ratios [HRs], primary analyses) or risk ratios (RRs, secondary analyses) together with precision estimates ( $95 \%$ confidence interval $[\mathrm{CI}])$ comparing underweight $\left(\mathrm{BMI}=<18.5 \mathrm{~kg} / \mathrm{m}^{2}\right)$, overweight $\left(\mathrm{BMI}=25-29.9 \mathrm{~kg} / \mathrm{m}^{2}\right)$, or obesity $\left(B M I=\geq 30 \mathrm{~kg} / \mathrm{m}^{2}\right)$ against normal-weight $\left(\mathrm{BMI}=18.5-24.9 \mathrm{~kg} / \mathrm{m}^{2}[\text { reference group] })^{25}\right.$ regarding all-cause or specific-cause mortality. For each article, in addition to estimates, two investigators (NV and CC) extracted 
data about authors, publication year, study location, participants characteristics and their distribution among BMI categories, follow-up duration, number of deaths and covariates used in statistical analyses. When information on mortality and/or standard BMI groups, study authors were contacted to obtain unpublished data. These unpublished data were validated by the first or last authors of the studies from which these data were obtained. All these authors are coauthors of the present meta-analyses. When raw data were shared with us, these were independently analyzed by two authors of this meta-analysis (N.V. and E.C.). In addition to number of deaths per standard BMI category, we requested HR estimates adjusted for the maximum number of the following covariates: age (as continuous), gender, dementia, stroke, cancer, infectious diseases, diabetes, hypertension, established cardiovascular diseases, chronic obstructive pulmonary disease, disability (either categorical [i.e. disabled vs. non-disabled] or continuous [i.e. ADL score ${ }^{26}$ or Barthel Index $\left.^{27}\right]$ ), and changes in BMI at last observation carried forward. Risks could be included in the analysis when $\geq 15$ nursing-home residents were present in each compared BMI group.

\section{Outcomes}

The primary outcome was all-cause mortality. Secondary outcomes included mortality due to cardiovascular, cerebrovascular or infectious disease, and other causes, again taking normal-weight subjects as reference.

\section{Assessment of study quality}

The Newcastle-Ottawa Scale (NOS) ${ }^{28}$ was used to evaluate study quality. The NOS assigns a maximum of 9 points to studies of highest quality according to three quality parameters: selection, comparability, and outcome. Any discrepancies were addressed by a joint re-evaluation of the article (NV, EC and CC).

\section{Data synthesis and statistical analysis}

Analyses were performed by two independent investigators (NV, EC) using Comprehensive Meta-Analysis (CMA) 3 (http://www.meta-analysis.com). In primary analyses, pooled HRs and 95\%CIs of all-cause and specific-cause mortality for standard BMI categories were calculated using DerSimonian-Laird randomeffects models, ${ }^{29}$ considered adequate, given study number and characteristics. ${ }^{30}$ In secondary analyses, pooled, unadjusted RRs $\pm 95 \%$ CIs were also calculated for providing additional information on proportions 
1

2

3

4

5

6

7

8

9

10

11

12

13

14

15

16

17

18

19

20

21

22

23

24

25

26

27

28

29

30

31

32

33

34

35

36

37

38

39

40

41

42

43

44

45

46

47

48

49

50

51

52

53

54

55

56

57

58

59

60

of deaths for every BMI category. Heterogeneity across studies was assessed by the Cochrane $\mathrm{I}^{2}$ metric and chi square statistics. Given significant heterogeneity $(\mathrm{p}<0.05),{ }^{31}$ we conducted stratified analyses ${ }^{30}$ exploring effects of the following pre-specified moderators: study origin (European vs. North-American vs. Australasian), study quality (median split of the NOS score [NOS=7]), median number of adjustments used in HR analysis ( $<8$ vs. $\geq 8$ ), follow-up duration $(<4$ vs. $\geq 4$ years), accurate BMI ascertainment (studies reporting weight and height measurement even in bedridden patients vs. those not reporting it), and most frequent sources of bias according to NOS. Additionally, we conducted meta-regression analyses (unrestricted maximum likelihood method) using the NOS score, number of covariates entered into the Cox regression HR analyses and duration of follow-up as continuous variables. Finally, we assessed the presence of publication bias by visual inspection of Funnel plots. 


\section{RESULTS}

\section{Search}

Altogether, 342 non-duplicated articles were identified. After excluding 290 articles based on title/abstract review, 52 articles were retrieved for full text review (Figure S1). Of these, 36 studies met inclusion criteria, but none reported mortality in relationship to standard BMI categories. ${ }^{25}$ Instead, studies provided risk of mortality by study-specific BMI quantiles (quartiles, tertiles, etc) or continuous BMI. Therefore, we contacted authors $\geq 4$ times asking them for information about the number of participants and deaths (overall and cause-specific) within each BMI category to calculate RRs and for the adjusted HRs including the maximum number of covariates. Among the potentially eligible studies, 16 authors (Asia, $n=6$; North America, $n=6$; Europe, $n=4$ ) could not be reached or were unable to provide the required information (Table S2), leaving 20 studies for this meta-analysis. ${ }^{32-51}$

\section{Study and Population Characteristics}

The 20 meta-analyzed studies ${ }^{32-51}$ followed 19,538 participants (median=349 [interquartile range, IQR=1931135]) in Europe $(n=8)$, Asia $(n=9)$, USA/Canada $(n=2)$, and Australia $(n=1)$. Participants were 84.2 $(\mathrm{IQR}=80.7-84.8)$ years old, $71.5 \%$ were females, with a median $\mathrm{BMI}=23.6(\mathrm{IQR}=21.7-25.1) \mathrm{kg} / \mathrm{m}^{2}$, and a median follow-up duration of 2, IQR=1, 4.75 years. Altogether, $16 \%$ were underweight, $50 \%$ were normal weight, 24\% were overweight, and 10\% were obese (Table 1). Conversely, the 16 studies excluded from this analysis (data no longer available; Table S2) had a median age of $84.0(\mathrm{IQR}=82.5-86)$ years, $68.7 \%$ were females, with a median $\mathrm{BMI}=22.2(\mathrm{IQR}=21.3-23.2) \mathrm{kg} / \mathrm{m}^{2}$, and a median follow-up duration of 0.5 (range: 0.5-2) years. Six studies included less than 349 residents, the median value of the studies included in our meta-analysis, while one followed prospectively more than one thousand residents.

The median NOS score was $7(\mathrm{IQR}=5-8)$. The most common sources of bias in prospective studies were the ascertainment of exposure and the length of follow-up. Particularly, although BMI was measured by trained personnel in all studies, appropriate assessment of BMI in all participants (including those bed-ridden) was reported only in 6 studies (30\%) while duration of follow-up appeared adequate ( $\geq 5$ years) in only 7 (35\%) studies (Table S3). 


\title{
TABLE 1
}

\begin{abstract}
All-Cause Mortality
Altogether, 5,223 deaths occurred. The raw numbers of deaths per BMI group were: underweight=1,500/4,194 (35.7\%); normal weight=2,646/10,281 (25.7\%); overweight=825/3,677 (22.4\%); obese $=252 / 1,386(18.2 \%)$. Compared to normal weight status, underweight was associated with a significant higher risk for all-cause mortality $(\mathrm{HR}=1.41$ [95\%CI, 1.26-1.58], $\mathrm{p}<0.001)$, while a reduction in risk was observed for overweight $(\mathrm{HR}=0.85$ [95\%CI, 0.73-0.99], $\mathrm{p}=0.04)$ and obesity $(\mathrm{HR}=0.74$ [95\%CI, 0.57-0.96], $\mathrm{p}=0.02$ ) (Table 2; Table 3). Funnel plot inspection indicated that publication bias was unlikely.
\end{abstract}

\section{TABLE 2-3}

Unadjusted RR analyses were consistent with HR results adjusted for potential confounders. However, allcause mortality was reduced also with overweight ( $R R=0.80$ [95\% CI $=0.72-0.88], p<0.001)$ (Figure 1A, Figure S2A).

\section{FIGURE 1}

Since HR results were significantly heterogeneous for all BMI categories, we investigated the role of potential moderators (Table 4). Study origin appeared to be a source of heterogeneity only for underweight estimates $(\mathrm{p}=0.001)$. Risk associated with all BMI categories remained significant only in studies performed in European countries. A consistent reduction in mortality risk heterogeneity was also observed. Among investigations conducted in Asia and Australia, significantly higher mortality risks for underweight and lower mortality risks for overweight were also confirmed, without heterogeneity. Heterogeneity was not associated with study quality. However, while underweight was associated with increased risk regardless of NOS score, a significant reduction in all-cause mortality associated with overweight and obesity was present only in high-quality $(\mathrm{NOS} \geq 7)$ studies. High study quality was also responsible for a consistent reduction in heterogeneity of all-cause mortality risk among underweight participants. The number of adjustments did not 
explain mortality risk heterogeneity. Besides, while a lower number of adjustment in the HR analyses confirmed risk estimates for all BMI categories and was associated with no/low heterogeneity, full adjustment appeared to result in no change in risk for overweight and obese participants. We evaluated also the role of follow-up duration and the ascertainment of BMI as they were the most frequent source of bias and determinants of study quality. Interestingly, the pooling of studies with follow-up $\geq 4$ years ${ }^{32,33,37,41,42,50,51}$ and accurate BMI ascertainment even of bedridden people $\mathrm{e}^{35-38,48,49}$ resulted in no heterogeneity in risk estimates for any of the BMI categories. Underweight still had a negative prognostic role in any strata investigated. Overweight status remained significantly associated with lower mortality in studies with longer duration and not reporting BMI ascertainment in bedridden residents, while obesity had a confirmed protective effect only in studies with duration $\geq 4$ years and those including an accurate ascertainment of BMI even in bedridden people. Finally, meta-regression analyses using continuous variables as moderators substantially confirmed that study quality and duration and adjustment of analyses were not relevant sources of heterogeneity. Only study quality appeared to influence HR risk estimates in obese residents $(p=0.04)$.

\section{TABLE 4}

\section{Specific-Cause Mortality}

The specific-cause mortality analysis included 9 studies $^{32,35-37,39,41,42,44,47}$ and 5,781 participants with 3,150 deaths (54.4\%), which were due to cardio-vascular diseases in 705 residents (22.4\%), cerebro-vascular conditions in 414 (13.0\%), infections in 923 (29.0\%), and other causes in 1,108 participants (35.6\%).

Underweight was associated with a significant increased risk of mortality due to infections $(+65 \%$; $\mathrm{p}=0.010)$, and cardio-vascular $(+34 \% ; \mathrm{p}=0.002)$ as well as cerebro-vascular diseases $(+64 \% ; \mathrm{p}=0.003)$, while other causes of mortality were only marginally significantly increased $(+29 ; \mathrm{p}=0.060)$. Conversely, overweight and obesity did not affect any of the specific-cause mortality events using HR analyses (Table 1).

In RR analyses (Figures 1 B-E; Figure S2 B-E), underweight was only associated with higher specificcause mortality due to infectious diseases $(\mathrm{RR}=1.47,95 \% \mathrm{CI}=1.12-1.92, \mathrm{p}=0.006)$. Like in HR analyses, overweight and obesity did not differ from normal weight regarding cardiovascular, cerebrovascular and 
1

2

3

4

5

6

7

8

9

10

11

12

13

14

15

16

17

18

19

20

21

22

23

24

25

26

27

28

29

30

31

32

33

34

35

36

37

38

39

40

41

42

43

44

45

46

47

48

49

50

51

52

53

54

55

56

57

58

59

60

other-cause mortality. However, compared to normal weight status, mortality from infectious diseases was significantly reduced with overweight, and obesity.

The results of the HR analyses were not significantly heterogeneous, except when considering the comparison between underweight and normal weight for death from infections $\left(I^{2}=61.6 \%\right)$. Only the number of adjustment used in the analyses appeared to be a source of heterogeneity $(\mathrm{p}=0.02)$. The increased risk of mortality due to infections associated with underweight status was confirmed in every strata $(<8, \mathrm{HR}=2.75$ [95\%CI, 1.54-4.90], $\mathrm{p}=0.001 ; \geq 8, \mathrm{HR}=1.24$ [95\%CI, 1.01-1.51], $\mathrm{p}=0.04$ ). No meta-regression procedure was conducted for all other comparisons and causes of death. Funnel plots inspection indicated that publication bias was unlikely. 


\section{DISCUSSION}

To our knowledge, this is the first meta-analysis investigating the relationship between standard BMI categories and all-cause and specific-cause mortality in old nursing-home residents. As hypothesized, overweight status was protective for all-cause mortality compared to underweight and normal weight status. However, obesity was also associated with lower all-cause mortality. A series of meta-regression analyses was also conducted, but all-cause mortality risk was unlikely related to country of study conduct, study quality and adequate adjustment of estimates. Finally, underweight was a risk factor for death from infections and both cardio-vascular and cerebro-vascular diseases. Notably, in RR analyses of incidence rates, overweight and obese status were also associated with reduced mortality from infections compared to normal weight.

Underweight has consistently been associated with greater all-cause mortality, regardless of age but more likely in the old adults. ${ }^{8,52-56}$ In fact, underweight is often related to cancer and consequently to higher mortality in younger populations as well as to frailty in the elderly. In contrast to present epidemiologic data, obesity has previously also been associated with higher future mortality compared to normal weight individuals $^{3,57-60}$ even independently of metabolic abnormalities. ${ }^{61}$ Nevertheless, these studies mainly included middle aged participants, limiting the application of these results to older people and the growing nursing-home population. Consistent with prior meta-analyses in adult ${ }^{20}$ and $\operatorname{old}^{17}$ general population, overweight old nursing-home residents had a reduced all-cause mortality risk in our analyses. However, obesity was not protective of all-cause mortality as found in our main analyses and most sensitivity/moderator analyses.

Several reasons could explain our results. First, the median age of populations included in our meta-analysis was $>80$ years. In the meta-analysis of community dwelling adults ${ }^{20}$ estimates were provided for people aged $\geq 65$ years, but when looking at the few studies conducted in very old subjects, a protective effect of mild obesity was suggested. ${ }^{4,12}$ Likely, with advancing age BMI decreases due to modifications of food intake and physical activity, multiple chronic and acute diseases, hormonal changes, and weight loss. ${ }^{5,6}$ Second, although BMI is a useful marker of weight accumulation and adiposity, previous population data analyses 
have shown that the relationship between BMI and fat mass - particularly in the obesity range - is not linear, while the relationship between BMI and fat-free mass is linear. ${ }^{62}$ Accordingly, higher BMI values are generally associated with higher fat-free mass, which is independently related to lower mortality. ${ }^{63}$ Nonetheless, in catabolic conditions, higher fat mass could confer survival advantages. ${ }^{41,64}$ However, there is also a physiological difference between older and younger people. In younger people, a large increase in fat mass could result in greater insulin resistance than in older subjects with an increased risk of unfavorable outcomes, like diabetes and cardiovascular diseases, which are characterized by high mortality. ${ }^{65}$ Third, normal weight people at the time of death could represent a high-risk group for mortality because they may have been overweight or obese and lost unintentionally substantial weight due to decreased appetite and food intake and/or chronic (undetected) medical or mental illness, reducing resilience and immunity ${ }^{66,67}$ Fourth, old overweight and obese individuals could be survivors of detrimental effects of higher BMI at younger age, representing a selected subgroup of more resilient individuals. This issue, which may be a relevant factor for the analyzed population that is characterized by a mean age over 80 years, should be investigated in future studies. At least for HR calculations, it was not possible to obtain estimates for different degrees of obesity due to the limited number of cases. Fifth, the median follow-up period of 2 years (range $=0.5-9$ years) could have been too short to show detrimental effects of obesity. However, obesity had a confirmed protective effect in studies with longer follow-up duration. Nevertheless, some authors primarily focusing on subjects aged 18-60 years, proposed that it takes about 15 years or more for obesity to exert its full impact on mortality. ${ }^{68,69}$ Finally, the lack of a significant association between increasing BMI and mortality found among studies with adequate adjustment could suggest that part of the protective effect of overweight and obesity may be mediated by interactions with comorbidities, although over-adjustment could also be taken into account.

Regarding underweight, the present meta-analysis confirms findings from almost all previous prospective investigations, regardless of study setting. The highest all-cause mortality rates were observed in underweight subjects, extending to each specific cause. Infections and cardiovascular disease are the leading causes of death in nursing-home residents. ${ }^{70,71}$ Both of these mortality causes were significantly elevated in underweight individuals, while at least in RR analyses, overweight and obesity were protective regarding death from infectious diseases compared to normal weight status. Malnutrition is responsible for the 
impairment of immune functions. ${ }^{72}$ Although urinary tract, skin and soft tissue infections are common, also due to the high prevalence of pressure ulcers and use of indwelling urinary catheters, pneumonia - frequently originating from aspiration in a highly neurologic and dysphagic population - is the most frequent cause and has the highest mortality. ${ }^{70,71}$ This outcome is likely related also to the paucity of clinical signs characterizing pneumonia in nursing-homes. ${ }^{70,72}$ Finally, although the association between vascular mortality and low body weight is intriguing - as it likely occurs in the absence of metabolic abnormalities - it may be explained by inflammatory and hormonal changes (e.g., glucocorticoids and catecholamines) and the dysregulation of the autonomic nervous system occurring with malnutrition and aging. ${ }^{73-76}$

This study has limitations. First, the most important shortcoming is that we excluded 16 potentially eligible studies since data were no longer available (see Table S2). In particular, we excluded six studies from North America where overweight and obesity are more common than in other continents, introducing a possible bias. However, the overall median BMI of the excluded studies was similar to or lower than ours, and the short follow-up duration compared to ours indicates that the excluded studies would have contributed less to clarifying the desired longer-term outcomes. Moreover, some of these studies seems to corroborate our and previous findings. Two studies, ${ }^{77,78}$ reported that low BMI was associated to increased mortality compared to higher BMI, while another reported that higher BMI values resulted in decreased mortality. ${ }^{79}$ Furthermore, Grabowski et al. reported that underweight and mild obesity were associated with increased and decreased all-cause, respectively, when compared to normal BMI. ${ }^{80}$ Although a selection bias cannot be excluded, we also found that relevant characteristics features of participants from the excluded studies (age, BMI, gender) were similar to those included in our meta-analysis. However, the majority of studies without metaanalyzable data that had to be excluded (10/16) followed more than 349 participants, which is the median value of the studies included in our work. On the other hand, this potential advantage of the excluded studies is clearly off-set by the shorter follow-up. Nevertheless, even if the excluded studies may create a bias, it would be hard to argue that this bias would be systematic in one or another direction. Second, we could not control for some factors that are associated with mortality risk, including smoking, number/type of medical and psychiatric morbidities, socioeconomic status, duration of institutionalization, habitual BMI, unintentional weight loss, race, and frailty. Moreover, the indications for institutionalization might differ 
considerably across countries, although a large study from 8 European countries suggest that the most important predictors (i.e., neuropsychiatric symptoms, care dependency and poor cognitive status) were similarly prevalent and important across the different countries. ${ }^{81}$ Another point is the possibly different life expectancy across countries included in our meta-analysis. However, as reported by the WHO, ${ }^{82}$ the countries included in our study had an expected life expectancy ranging from 76 to 84 years suggesting that the risk of bias due to this factor is likely not very large. Furthermore, adjustment of mortality risks by relevant covariates was heterogeneous. Third, we considered only BMI and no other body composition parameters, including fat-free BMI indicators. However, BMI is an accepted proxy for other, more sophisticated or regionally specific indices of adiposity, performing generally equally well in predicting mortality in old adults. ${ }^{11}$ Fourth, we could not assess different grades of obesity in HR analyses. However, consistent with our RR findings, the only study investigating high grade obesity in nursing-home residents detected an association between $\mathrm{BMI} \geq 40$ and increased mortality, ${ }^{80}$ indicating that high grade obesity is likely not protective and needs to be addressed adequately. Fifth, many studies were of relatively short duration and the median follow-up was only 2 years. However, we confirmed the findings in the studies with $\geq 4$ years of follow-up and study duration was not a significant moderator of the results. Sixth, we included four studies with a NOS score $<5$, which is indicative of high risk of bias. However, although study quality appeared to be a relevant source of bias, sub-analyses of high-quality studies confirmed the estimates obtained from all studies with a partial reduction of heterogeneity. Finally, 11 out of 20 studies had less than 400 participants, and most were not powered to specifically address mortality, particularly due to specific causes. Despite these limitations, this is the first meta-analysis examining all-cause and specific-cause mortality in old nursing-home residents across standard BMI categories. Our results stress the importance of weighing nursing-home residents regularly, guarding against unintentional weight loss and focusing not only on underweight and its treatment by nutritional support, but also on normal weight individuals who may need to be reclassified as a moderate-risk group for mortality when cared for in nursing-home settings. This view is consistent with previous guidelines suggesting a $\mathrm{BMI}<21 \mathrm{~kg} / \mathrm{m}^{2}$ as an useful trigger for nutritional support. ${ }^{35}$ Finally, obese nursing-home residents, who require more complex care, should likely not ubiquitously be encouraged to lose weight, although this may facilitate their physical handling and mobilization. 
In conclusion, as in the general population, underweight is a risk factor for increased all-cause and specific cause mortality in nursing-home residents. Conversely, both overweight and obesity are likely protective for survival in this population. Thus, pros and cons of intended weight loss in obese old subjects need to be weighed carefully. Future studies should assess the effects of body composition parameters, weight trajectories, immobility, duration of institutionalization, comorbidities, and medications, and should evaluate death from specific infections, in order to provide explanations of the observed findings. Despite the protective effect, one also needs to consider the negative impact of high BMI on co-morbidities, disability, poor physical performance and low quality of life ${ }^{66,67}$ Further research is needed to identify ways to prevent elevated mortality in underweight as well as normal weight individuals, with nutritional support being an obvious target. ${ }^{35}$ 


\section{ACKNOWLEDGMENT SECTION}

We would like to thank every co-author participating in this work for giving us their data and for their support.

\section{Funding/Support: none.}

Financial Disclosure: Drs. Audrey, Abe, Arendt, Beck, Chan, Diekmann, Maggi, Solmi, Fowler, Manzato, Kimyagarov, Sergi, Smiley, Lok, Manu, Hayashi, Wen-Yuan Lin, Hua-Shui Hsu, Cheng-Chieh Lin, Lee, Cameron, Miller, Nakamura, Sund Levander, Rondanelli, Schindler, Valentini, Wong, Veronese,Volpato and Zuliani have nothing to disclose.

Dr. Allard is a consultant/speaker for Abbott and Baxter Corp and received honararia. In addition, she received unrestricted grants from Baxter, Abbott, Fresenius-Kabi, Pfizeer and Nestle.

Dr. Cereda has been a consultant and/or advisor to or has received honoraria from Nutricia, Wunder and Akern.

Dr. Pitkäla has given lectures supported by Lundbeck and Orion.

Dr. Woo has received honoraria from Sanofi-Aventis, MSD, GSK, Abbott.

Dr. Umpierrez has received research grant support (to Emory University) from Sanofi, Novo Nordisk, Boehringer Ingelheim and Merck, and has been a consultant for Sanofi, Novo Nordisk, Merck, Boehringer Ingelheim, and Regeneron.

Dr. Kane has been a consultant and/or advisor to or has received honoraria from: Alkermes, Amgen, BristolMyers Squibb, Eli Lilly, Esai, Forrest Labs, Genentech, Gerson Lehman Group, IntraCellular Therapies, Janssen, Jazz, J \& J, Lundbeck, MedAvante, Merck, Novartis, Otsuka, Pierre Fabre, Proteus, Pfizer, Roche, Reviva, Sunovion, Takeda, Targacept, Vanda. He is a shareholder of MedAvante.

Dr. Correll has been a consultant and/or advisor to or has received honoraria from: AbbVie, Actelion, Alexza; American Academy of Child and Adolescent Psychiatry, Bristol-Myers Squibb, Cephalon, Eli Lilly, Genentech, GersonLehrman Group, IntraCellular Therapies, Lundbeck, Medavante, Medscape, Merck, National Institute of Mental Health, Janssen/J\&J, Otsuka, Pfizer, ProPhase, Reviva, Roche, Sunovion, Takeda, Teva, and Vanda. He has received grant support from BMS, Feinstein Institute for Medical Research, Janssen/J\&J, National Institute of Mental Health (NIMH), National Alliance for Research in Schizophrenia and Depression (NARSAD), Otsuka and Takeda. 


\section{REFERENCES}

1. Berrington de Gonzalez A, Hartge P, Cerhan JR, et al. Body-mass index and mortality among 1.46 million white adults. $N$ Engl J Med. 2010;363(23):2211-2219.

2. Allison DB, Faith MS, Heo M, Kotler DP. Hypothesis concerning the U-shaped relation between body mass index and mortality. Am J Epidemiol. 1997;146(4):339-349.

3. Tobias DK, Pan A, Jackson CL, et al. Body-mass index and mortality among adults with incident type 2 diabetes. $N$ Engl J Med. 2014;370(3):233-244.

4. Mattila K, Haavisto M, Rajala S. Body mass index and mortality in the elderly. Br Med J (Clin Res Ed). 1986;292(6524):867-868.

5. Muscaritoli M, Anker SD, Argilés J, et al. Consensus definition of sarcopenia, cachexia and precachexia: joint document elaborated by Special Interest Groups (SIG) "cachexia-anorexia in chronic wasting diseases" and "nutrition in geriatrics". Clin Nutr. 2010;29(2):154-9.

6. Cruz-Jentoft AJ, Baeyens JP, Bauer JM, et al. Sarcopenia: European consensus on definition and diagnosis: Report of the European Working Group on Sarcopenia in Older People. Age Ageing. 2010;39(4):412-23.

7. Taylor DH, Ostbye T. The effect of middle- and old-age body mass index on short-term mortality in older people. J Am Geriatr Soc. 2001;49(10):1319-1326

8. Sergi G, Perissinotto E, Pisent $\mathrm{C}$, et al. An adequate threshold for body mass index to detect underweight condition in elderly persons: the Italian Longitudinal Study on Aging (ILSA). J Gerontol A Biol Sci Med Sci. 2005;60(7):866-871

9. Flegal KM, Graubard BI, Williamson DF, Gail MH. Excess deaths associated with underweight, overweight, and obesity. JAMA. 2005;293(15):1861-1867

10. Oreopoulos A, Kalantar-Zadeh K, Sharma AM, Fonarow GC. The obesity paradox in the elderly: potential mechanisms and clinical implications. Clin Geriatr Med. 2009;25(4):643-659, viii

11. Kuk JL, Ardern CI. Influence of age on the association between various measures of obesity and allcause mortality. J Am Geriatr Soc. 2009;57(11):2077-2084

12. Dahl AK, Fauth EB, Ernsth-Bravell M, Hassing LB, Ram N, Gerstof D. Body mass index, change in 
body mass index, and survival in old and very old persons. $J$ Am Geriatr Soc. 2013;61(4):512-518

13. Jialin W, Yi Z, Weijie Y. Relationship between body mass index and mortality in hemodialysis patients: a meta-analysis. Nephron Clin Pract. 2012;121(3-4):c102-111

14. Pickkers P, de Keizer N, Dusseljee J, Weerheijm D, van der Hoeven JG, Peek N. Body mass index is associated with hospital mortality in critically ill patients: an observational cohort study. Crit Care Med. 2013;41(8):1878-1883

15. Iozzo P, Rossi G, Michelassi C, Landi P, Carpeggiani C. Interpretation of the "obesity paradox": a 30year study in patients with cardiovascular disease. Int J Cardiol. 2013;168(1):112-116.

16. Stein PD, Matta F, Goldman J. Obesity and pulmonary embolism: the mounting evidence of risk and the mortality paradox. Thromb Res. 2011;128(6):518-523.

17. Romero-Corral A, Montori VM, Somers VK, et al. Association of bodyweight with total mortality and with cardiovascular events in coronary artery disease: a systematic review of cohort studies. Lancet. 2006;368(9536):666-678.

18. Greenberg JA. The obesity paradox in the US population. Am J Clin Nutr. 2013;97(6):1195-1200

19. Dixon JB, Lambert GW. The obesity paradox--a reality that requires explanation and clinical interpretation. Atherosclerosis. 2013;226(1):47-48.

20. Flegal KM, Kit BK, Orpana H, Graubard BI. Association of all-cause mortality with overweight and obesity using standard body mass index categories: a systematic review and meta-analysis. JAMA. 2013;309(1):71-82.

21. Katz PR. An international perspective on long term care: focus on nursing homes. J Am Med Dir Assoc. 2011;12(7):487-492.

22. Stroup DF, Berlin JA, Morton SC, et al. Meta-analysis of observational studies in epidemiology: a proposal for reporting. Meta-analysis Of Observational Studies in Epidemiology (MOOSE) group. JAMA. 2000;283(15):2008-2012

23. Liberati A, Altman DG, Tetzlaff J, et al. The PRISMA statement for reporting systematic reviews and meta-analyses of studies that evaluate healthcare interventions: explanation and elaboration. $B M J$. 2009;339:b2700

24. Obesity: preventing and managing the global epidemic. Report of a WHO consultation. World Health 
Organ Tech Rep Ser. 2000;894:i-xii, 1-253

25. Katz S, Downs TD, Cash HR, Grotz RC. Progress in development of the index of ADL. Gerontologist. $1970 ; 10(1): 20-30$

26. Mahoney F, Barthel D. Functional evaluation: the Barthel Index. Md State Med J. 1965;14:61-65

27. Wells GA, Shea B, O'Connell D, et al. The Newcastle-Ottawa Scale (NOS) for assessing the quality of nonrandomised studies in meta-analyses.

http://www.ohri.ca/programs/clinical_epidemiology/oxford.htm (last access: 05/31/14)

28. DerSimonian R, Laird N. Meta-analysis in clinical trials. Control Clin Trials. 1986;7(3):177-188.

29. Cornell JE, Mulrow CD, Localio R, et al. Random-effects meta-analysis of inconsistent effects: a time for change. Ann Intern Med. 2014; 160(4):267-70.

30. Higgins JP, Thompson SG. Quantifying heterogeneity in a meta-analysis. Stat Med. 2002;21(11):15391558.

31. Abe E, Hayashi K, Matsumura Y, Sugai Y. Unintentional weight loss in the elderly at a nursing home in Japan: Time of onset, changes, and association with mortality. Kitakanto Medical Journal. 2011;61(4):471-478.

32. Allard JP, Aghdassi E, McArthur M, et al. Nutrition risk factors for survival in the elderly living in Canadian long-term care facilities. J Am Geriatr Soc. 2004;52(1):59-65.

33. Beck AM, Damkjaer K. Optimal body mass index in a nursing home population. J Nutr Health Aging. 2008;12(9):675-677.

34. Cereda E, Pedrolli C, Zagami A, et al. Body mass index and mortality in institutionalized elderly. $J$ Am Med Dir Assoc. 2011;12(3):174-178.

35. Chan M, Lim YP, Ernest A, Tan TL. Nutritional assessment in an Asian nursing home and its association with mortality. J Nutr Health Aging. 2010;14(1):23-28.

36. Hsu HS, Li CI, Liu CS, et al. Iron deficiency is associated with increased risk for cardiovascular disease and all-cause mortality in the elderly living in long-term care facilities. Nutrition. 2013;29(5):737-743.

37. Kaiser R, Winning K, Uter W, et al. Functionality and mortality in obese nursing home residents: an example of 'risk factor paradox'? J Am Med Dir Assoc. 2010;11(6):428-435.

38. Kimyagarov S, Klid R, Levenkrohn S, et al. Body mass index (BMI), body composition and mortality of 
nursing home elderly residents. Arch Gerontol Geriatr. 2010;51(2):227-230.

39. Kuikka LK, Salminen S, Ouwehand A, et al. Inflammation markers and malnutrition as risk factors for infections and impaired health-related quality of life among older nursing home residents. J Am Med Dir Assoc. 2009;10(5):348-353.

40. Lee JS, Auyeung TW, Chau PP, et al. Obesity can benefit survival-a 9-year prospective study in 1614 Chinese nursing home residents. J Am Med Dir Assoc. 2014;15(5):342-348.

41. Lin WY, Albu J, Liu CS, et al. Larger body mass index and waist circumference are associated with lower mortality in Chinese long-term care facility residents. J Am Geriatr Soc. 2010;58(11):2092-2098.

42. Lok K, Woo J, Hui E, Kwok T. Usefulness of the Chinese Nutrition Screening (CNS) tool in predicting 12 month mortality in elderly Hong Kong Chinese living in institutions. J Nutr Health Aging. 2009;13(2):96-101.

43. Miller MD, Thomas JM, Cameron ID, et al. BMI: a simple, rapid and clinically meaningful index of under-nutrition in the oldest old? Br J Nutr. 2009;101(9):1300-1305.

44. Nakazawa A, Nakamura K, Kitamura K, Yoshizawa Y. Association between body mass index and mortality among institutionalized elderly adults in Japan. Environ Health Prev Med. 2013;18(6):502506.

45. Smiley D, Olson DE, Sadeghi-Yarandi S, et al. Glycemic control and clinical outcome in nursing home residents with diabetes: A multicenter observational study. Diabetes. 2012;61:A289-A290.

46. Sund-Levander M, Grodzinsky E, Wahren LK. Gender differences in predictors of survival in elderly nursing-home residents: a 3-year follow up. Scand J Caring Sci. 2007;21(1):18-24.

47. Törmä J, Winblad U, Cederholm T, Saletti A. Does undernutrition still prevail among nursing home residents? Clin Nutr. 2013;32(4):562-568.

48. Valentini L, Schindler K, Schlaffer R, et al. The first nutritionDay in nursing homes: participation may improve malnutrition awareness. Clin Nutr. 2009;28(2):109-116.

49. Veronese N, De Rui M, Toffanello ED, et al. Body mass index as a predictor of all-cause mortality in nursing home residents during a 5-year follow-up. J Am Med Dir Assoc. 2013;14(1):53-57.

50. Volpato S, Romagnoni F, Soattin L, et al. Body mass index, body cell mass, and 4-year all-cause mortality risk in older nursing home residents. J Am Geriatr Soc. 2004;52(6):886-891. 
51. Strandberg TE, Strandberg AY, Salomaa VV, et al. Explaining the obesity paradox: cardiovascular risk, weight change, and mortality during long-term follow-up in men. Eur Heart J. 2009;30(14):1720-1727.

52. Lancefield T, Clark DJ, Andrianopoulos N, et al. Is there an obesity paradox after percutaneous coronary intervention in the contemporary era? An analysis from a multicenter Australian registry. JACC Cardiovasc Interv. 2010;3(6):660-668.

53. Wu CY, Chou YC, Huang N, et al. Association of body mass index with all-cause and cardiovascular disease mortality in the elderly. PLoS One. 2014;9(7):e102589.

54. Ma J, Jemal A, Flanders WD, Ward EM. Joint association of adiposity and smoking with mortality among U.S. adults. Prev Med. 2013;56(3-4):178-84.

55. de Hollander EL, Bemelmans WJ, Boshuizen HC, et al. The association between waist circumference and risk of mortality considering body mass index in 65- to 74-year-olds: a meta-analysis of 29 cohorts involving more than 58000 elderly persons. Int J Epidemiol. 2012; 41(3):805-17.

56. Fontaine KR, McCubrey R, Mehta T, et al. Body mass index and mortality rate among Hispanic adults: a pooled analysis of multiple epidemiologic data sets. Int J Obes (Lond). 2012;36(8):1121-1126.

57. Song X, Jousilahti P, Stehouwer CD, et al. Cardiovascular and all-cause mortality in relation to various anthropometric measures of obesity in Europeans. Nutr Metab Cardiovasc Dis. 2015; 25(3):295-304.

58. Kitahara CM, Flint AJ, Berrington de Gonzalez A et al. Association between class III obesity (BMI of $40-59 \mathrm{~kg} / \mathrm{m} 2$ ) and mortality: a pooled analysis of 20 prospective studies. PLoS Med. 2014;11(7): e1001673.

59. Tsai AC, Hsiao ML. The association of body mass index (BMI) with all-cause mortality in older Taiwanese: results of a national cohort study. Arch Gerontol Geriatr. 2012;55(2):217-220.

60. Thomsen M, Nordestgaard BG. Myocardial infarction and ischemic heart disease in overweight and obesity with and without metabolic syndrome. JAMA Intern Med. 2014;174(1):15-22.

61. Winter JE, MacInnis RJ, Wattanapenpaiboon N, Nowson CA. BMI and all-cause mortality in older adults: a meta-analysis. Am J Clin Nutr. 2014; 99:875-90.

62. Genton L, Graf CE, Karsegard VL, Kyle UG, Pichard C. Low fat-free mass as a marker of mortality in community-dwelling healthy elderly subjects. Age Ageing. 2013;42(1):33-9.

63. Bouillanne O, Dupont-Belmont C, Hay P, Hamon-Vilcot B, Cynober L, Aussel C. Fat mass protects 
hospitalized elderly persons against morbidity and mortality. Am J Clin Nutr. 2009;90(3):505-10.

64. Bradway C, DiResta J, Fleshner I, Polomano RC. Obesity in nursing homes: a critical review. J Am Geriatr Soc. 2008;56(8):1528-35.

65. Chapman IM. Obesity paradox during aging. Interdiscip Top Gerontol. 2010;37:20-36.

66. Zanandrea V, Barreto de Souto P, Cesari M, Vellas B, Rolland Y. Obesity and nursing home: a review and an update. Clin Nutr. 2013;32(5):679-85.

67. Dyer AR, Stamler J, Garside DB, Greenland P. Long-term consequences of body mass index for cardiovascular mortality: the Chicago Heart Association Detection Project in Industry study. Ann Epidemiol. 2004;14(2):101-8.

68. Kramer CK, Zinman B, Retnakaran R. Are metabolically healthy overweight and obesity benign conditions?: A systematic review and meta-analysis. Ann Intern Med. 2013;159(11):758-69.

69. Gorzoni ML, Pires SL. Deaths in nursing homes. Rev Assoc Med Bras. 2011;57(3):327-31.

70. Lim WS, Macfarlane JT. A prospective comparison of nursing home acquired pneumonia with community acquired pneumonia. Eur Respir J. 2001;18(2):362-8.

71. Norman K, Pichard C, Lochs H, Pirlich M. Prognostic impact of disease-related malnutrition. Clin Nutr. 2008;27(1):5-15.

72. Ayaz S, Haque N, Pearson C, Medado P, Robinson D, Wahl R, et al. Nursing home-acquired pneumonia: course and management in the emergency department. Int J Emerg Med. 2014;7:19.

73. Avraham Y, Hao S, Mendelson S, Berry EM. Hypothalamic-pituitary-adrenal responses to weight loss in mice following diet restriction, activity or separation stress: effects of tyrosine. Nutr Neurosci. 2002;5:327-35.

74. Yeh SS, Schuster MW. Geriatric cachexia: the role of cytokines. Am J Clin Nutr. 1999;70:183-97.

75. Venihaki M, Dikkes P, Carrigan A, Karalis KP. Corticotropin-releasing hormone regulates IL-6 expression during inflammation. J Clin Invest. 2001;108:1159-66.

76. Kiely DK, Flacker JM. Resident characteristics associated with mortality in long-term care nursing homes: is there a gender difference? J Am Med Dir Assoc. 2000; 1: 8-13.

77. Kiely DK, Flacker JM. Common and gender specific factors associated with one-year mortality in nursing home residents. J Am Med Dir Assoc. 2002;3: 302-309. 
78. Sullivan DH, Johnson LE, Bopp MM, Roberson PK. Prognostic significance of monthly weight fluctuations among older nursing home residents. J Gerontol A Biol Sci Med Sci. 2004;59:633-639.

79. Grabowski DC, Campbell CM, Ellis JE. Obesity and mortality in elderly nursing home residents. $J$ Gerontol A Biol Sci Med Sci. 2005;60(9):1184-9.

80. Thomas DR, Ashmen W, Morley JE, Evans WJ. Nutritional management in long-term care: development of a clinical guideline. Council for Nutritional Strategies in Long-Term Care. $J$ Gerontol A Biol Sci Med Sci. 2000;55:M725-734.

81. Afram B, Stephan A, Verbeek H, et al. Reasons for institutionalization of people with dementia: informal caregiver reports from 8 European countries. J Am Med Dir Assoc. 2014;15(2):108-16.

82. World Health Organization. "Life expectancy Data by country". http://apps.who.int/gho/data/node.main.688?lang=en.(last access. 05/30/2015). 


\section{FIGURE LEGEND}

Figure 1. Pooled estimates (RRs) and 95\%CI for mortality risk associated with underweight, overweight and obesity compared to normal weight status (Plot A, all-cause mortality; Plot B, mortality due to infectious disease; Plot $C$, mortality due to cardiovascular causes; Plot D, mortality due to cerebrovascular causes; Plot $E$, mortality due to other causes). 
Table 1. Characteristics of the studies included

\begin{tabular}{|c|c|c|c|c|c|c|c|c|c|}
\hline Study/Country & Sample size & $\begin{array}{c}\text { Number } \\
\text { of } \\
\text { deaths }\end{array}$ & $\begin{array}{l}\text { Baseline } \\
\text { age }\end{array}$ & $\begin{array}{l}\text { Percentage } \\
\text { of females }\end{array}$ & $\begin{array}{c}\text { Baseline } \\
\text { BMI }\end{array}$ & $\begin{array}{l}\text { Percent in Specific } \\
\text { BMI Category }\end{array}$ & $\begin{array}{c}\text { Years of } \\
\text { follow- } \\
\text { up }\end{array}$ & $\begin{array}{l}\text { Newcastle- } \\
\text { Ottawa Scale }\end{array}$ & $\begin{array}{c}\text { Number of } \\
\text { adjustments * }\end{array}$ \\
\hline $\begin{array}{c}\text { Abe, } 2011 \\
\underset{32}{\text { Japan }}\end{array}$ & 244 & 173 & $84.7 \pm 7.5$ & 81.1 & $19.3 \pm 3.5$ & $\begin{array}{c}\text { Underweight: } 46 \% \\
\text { Normal Weight: } 47 \% \\
\text { Overweight: } 6 \% \\
\text { Obese: } 1 \% \\
\end{array}$ & 4 & 8 & 9 \\
\hline $\begin{array}{c}\text { Allard,2004 } \\
\text { Canada } \\
33\end{array}$ & 495 & 147 & $85.1 \pm 7.8$ & 67.2 & $24.4 \pm 5.6$ & $\begin{array}{c}\text { Underweight: } 13 \% \\
\text { Normal Weight: } 42 \% \\
\text { Overweight: } 29 \% \\
\text { Obese: } 16 \%\end{array}$ & 1.7 & 4 & 4 \\
\hline $\begin{array}{c}\text { Beck, } 2008 \\
\text { Denmark } \\
34\end{array}$ & 428 & 109 & $85.4 \pm 7.0$ & 79.9 & $23.5 \pm 5.0$ & $\begin{array}{c}\text { Underweight: } 15 \% \\
\text { Normal Weight: } 49 \% \\
\text { Overweight: } 25 \% \\
\text { Obese: } 11 \%\end{array}$ & 1 & 5 & 12 \\
\hline $\begin{array}{c}\text { Cereda, } 2011 \\
\text { Italy } \\
35\end{array}$ & 519 & 409 & $84.0 \pm 8.4$ & 90.2 & $23.1 \pm 4.7$ & $\begin{array}{c}\text { Underweight: } 15 \% \\
\text { Normal Weight: } 55 \% \\
\text { Overweight: } 22 \% \\
\text { Obese: } 8 \%\end{array}$ & 5.7 & 9 & 11 \\
\hline $\begin{array}{l}\text { Chan, 2010 } \\
\text { Singapore }\end{array}$ & 158 & 41 & $77.0 \pm 12.0$ & 51.0 & $18.7 \pm 3.6$ & $\begin{array}{c}\text { Underweight: } 51 \% \\
\text { Normal Weight: } 41 \% \\
\text { Overweight: } 7 \% \\
\text { Obese: } 1 \%\end{array}$ & 2 & 8 & 3 \\
\hline $\begin{array}{c}\text { Hsu, } 2013 \\
\text { Taiwan } \\
37\end{array}$ & 336 & 155 & $79.1 \pm 7.2$ & 46.1 & $21.7 \pm 4.8$ & $\begin{array}{c}\text { Underweight: } 21 \% \\
\text { Normal Weight: } 57 \% \\
\text { Overweight: } 18 \% \\
\text { Obese: } 4 \%\end{array}$ & 5 & 8 & 6 \\
\hline $\begin{array}{c}\text { Kaiser, } 2010 \\
\text { Germany } \\
38\end{array}$ & 200 & 47 & $85.5 \pm 7.8$ & 73.5 & $26.3 \pm 5.3$ & $\begin{array}{c}\text { Underweight: } 5 \% \\
\text { Normal Weight: } 40 \% \\
\text { Overweight: } 30 \% \\
\text { Obese: } 25 \%\end{array}$ & 1 & 5 & 4 \\
\hline $\begin{array}{c}\text { Kimyagarov, } \\
2010 \\
\text { Israel } \\
39\end{array}$ & 82 & 24 & $84.8 \pm 7.1$ & 57.3 & $25.2 \pm 4.1$ & $\begin{array}{c}\text { Underweight: } 1 \% \\
\text { Normal Weight: } 52 \% \\
\text { Overweight: } 35 \% \\
\text { Obese: } 12 \%\end{array}$ & 1 & 3 & 10 \\
\hline
\end{tabular}




\begin{tabular}{|c|c|c|c|c|c|c|c|c|c|}
\hline Study/Country & Sample size & $\begin{array}{c}\text { Number } \\
\text { of } \\
\text { deaths }\end{array}$ & $\begin{array}{l}\text { Baseline } \\
\text { age }\end{array}$ & $\begin{array}{l}\text { Percentage } \\
\text { of females }\end{array}$ & $\begin{array}{c}\text { Baseline } \\
\text { BMI }\end{array}$ & $\begin{array}{l}\text { Percent in Specific } \\
\text { BMI Category }\end{array}$ & $\begin{array}{c}\begin{array}{c}\text { Years of } \\
\text { follow- } \\
\text { up }\end{array} \\
\end{array}$ & $\begin{array}{l}\text { Newcastle- } \\
\text { Ottawa Scale }\end{array}$ & $\begin{array}{c}\text { Number of } \\
\text { adjustments * }\end{array}$ \\
\hline $\begin{array}{c}\text { Kuikka, } 2009 \\
\text { Finland } \\
40\end{array}$ & 191 & 25 & $84.9 \pm 4.6$ & 82.7 & $22.8 \pm 4.6$ & $\begin{array}{c}\text { Underweight: } 15 \% \\
\text { Normal Weight: } 59 \% \\
\text { Overweight: } 17 \% \\
\text { Obese: } 9 \%\end{array}$ & 0.7 & 5 & 5 \\
\hline $\begin{array}{l}\text { Lee, } 2014 \\
\text { China } \\
41\end{array}$ & 1614 & 1261 & $83.7 \pm 8.4$ & 69.5 & $21.7 \pm 4.8$ & $\begin{array}{c}\text { Underweight: } 26 \% \\
\text { Normal Weight: } 51 \% \\
\text { Overweight: } 18 \% \\
\text { Obese: } 5 \%\end{array}$ & 9 & 8 & 11 \\
\hline $\begin{array}{c}\text { Lin, } 2010 \\
\text { Taiwan } \\
42\end{array}$ & 354 & 219 & $78.4 \pm 7.8$ & 55.9 & $21.7 \pm 4.2$ & $\begin{array}{c}\text { Underweight: } 20 \% \\
\text { Normal Weight: } 54 \% \\
\text { Overweight: } 22 \% \\
\text { Obese: } 4 \% \\
\end{array}$ & 5 & 8 & 6 \\
\hline $\begin{array}{c}\text { Lok, } 2009 \\
\text { China }\end{array}$ & 525 & 67 & $81.0 \pm 7.9$ & 60.0 & $22.4 \pm 4.3$ & $\begin{array}{c}\text { Underweight: } 21 \% \\
\text { Normal Weight: } 56 \% \\
\text { Overweight: } 18 \% \\
\text { Obese: } 5 \%\end{array}$ & 1 & 4 & 7 \\
\hline $\begin{array}{l}\text { Miller, } 2009 \\
\text { Australia } \\
44\end{array}$ & 1827 & 613 & $80.6 \pm 1.3$ & 77.4 & $23.7 \pm 4.6$ & $\begin{array}{c}\text { Underweight: } 12 \% \\
\text { Normal Weight: } 53 \% \\
\text { Overweight: } 26 \% \\
\text { Obese: } 9 \%\end{array}$ & 2 & 7 & 5 \\
\hline$\underset{45}{\text { Napanazana, }} 2013$ & 8179 & 1081 & $84.3 \pm 8.1$ & 77.2 & $20.6 \pm 3.8$ & $\begin{array}{c}\text { Underweight: } 30 \% \\
\text { Normal Weight: } 58 \% \\
\text { Overweight: } 11 \% \\
\text { Obese: } 1 \%\end{array}$ & 1 & 7 & 3 \\
\hline $\begin{array}{c}\text { Smiley, } 2012 \\
\text { USA } \\
46\end{array}$ & 1339 & 193 & $79.7 \pm 12.0$ & 58.9 & $25.7 \pm 6.9$ & $\begin{array}{c}\text { Underweight: } 10 \% \\
\text { Normal Weight: } 42 \% \\
\text { Overweight: } 28 \% \\
\text { Obese: } 20 \%\end{array}$ & 2 & 3 & 9 \\
\hline $\begin{array}{c}\text { Sund-Levander, } \\
2007 \\
\text { Sweden } \\
47\end{array}$ & 234 & 132 & $84.6 \pm 6.8$ & 66.7 & $25.4 \pm 4.9$ & $\begin{array}{c}\text { Underweight: } 16 \% \\
\text { Normal Weight: } 47 \% \\
\text { Overweight: } 27 \% \\
\text { Obese: } 10 \%\end{array}$ & 3 & 6 & 11 \\
\hline
\end{tabular}




\begin{tabular}{|c|c|c|c|c|c|c|c|c|c|}
\hline Study/Country & Sample size & $\begin{array}{c}\begin{array}{c}\text { Number } \\
\text { of } \\
\text { deaths }\end{array} \\
\end{array}$ & $\begin{array}{l}\text { Baseline } \\
\text { age }\end{array}$ & $\begin{array}{l}\text { Percentage } \\
\text { of females }\end{array}$ & $\begin{array}{c}\text { Baseline } \\
\text { BMI }\end{array}$ & $\begin{array}{l}\text { Percent in Specific } \\
\text { BMI Category }\end{array}$ & $\begin{array}{c}\text { Years of } \\
\text { follow- } \\
\text { up }\end{array}$ & $\begin{array}{l}\text { Newcastle- } \\
\text { Ottawa Scale }\end{array}$ & $\begin{array}{c}\text { Number of } \\
\text { adjustments * }\end{array}$ \\
\hline $\begin{array}{c}\text { Torma, } 2013 \\
\text { Sweden } \\
48\end{array}$ & 172 & 41 & $86.3 \pm 7.7$ & 61.0 & $23.7 \pm 5.1$ & $\begin{array}{c}\text { Underweight: } 6 \% \\
\text { Normal Weight: } 39 \% \\
\text { Overweight: } 35 \% \\
\text { Obese: } 10 \%\end{array}$ & 1 & 7 & 11 \\
\hline $\begin{array}{c}\text { Valentini, } 2009 \\
\text { Germany }\end{array}$ & 2116 & 192 & $84.3 \pm 9.1$ & 79.3 & $24.9 \pm 5.4$ & $\begin{array}{c}\text { Underweight: } 9 \% \\
\text { Normal Weight: } 47 \% \\
\text { Overweight: } 28 \% \\
\text { Obese: } 15 \%\end{array}$ & 0.5 & 7 & 9 \\
\hline $\begin{array}{c}\text { Veronese, } 2013 \\
\text { Italy }\end{array}$ & 181 & 115 & $81.3 \pm 8.4$ & 80.1 & $25.4 \pm 4.8$ & $\begin{array}{c}\text { Underweight: } 4 \% \\
\text { Normal Weight: } 47 \% \\
\text { Overweight: } 34 \% \\
\text { Obese: } 15 \%\end{array}$ & 5 & 9 & 7 \\
\hline $\begin{array}{c}\text { Volpato, } 2004 \\
\text { Italy } \\
51\end{array}$ & 344 & 179 & $82.1 \pm 7.1$ & 79.1 & $24.1 \pm 4.6$ & $\begin{array}{c}\text { Underweight: } 10 \% \\
\text { Normal Weight: } 53 \% \\
\text { Overweight: } 26 \% \\
\text { Obese: } 11 \%\end{array}$ & 4 & 7 & 11 \\
\hline $\begin{array}{c}\text { All studies: } \\
20 \\
\text { Europe }=9 \text { studies } \\
\text { Asia }=7 \text { studies } \\
\text { USA } \text { Canada }=2 \\
\text { studies } \\
\text { Australia }=1 \text { study } \\
\text { Israel }=1 \text { study }\end{array}$ & $\begin{array}{c}19538 \\
\text { (median=349; } \\
\text { IQR=193.3- } \\
1135)\end{array}$ & 5223 & $\begin{array}{c}\text { Median }=84.2 \\
(I Q R=80.7 \\
-84.8)\end{array}$ & 71.5 & $\begin{array}{c}\text { Median }=23.6 \\
(I Q R=21.7- \\
25.1)\end{array}$ & $\begin{array}{c}\text { Underweight: } 16 \% \\
\text { Normal Weight: } \\
50 \% \\
\text { Overweight: } 24 \% \\
\text { Obese: } 10 \%\end{array}$ & $\begin{array}{c}\text { Median }= \\
2 \\
(I Q R=1 . \\
0-4.8)\end{array}$ & $\begin{array}{l}\text { Median }=7 \\
(I Q R=5-8)\end{array}$ & $\begin{array}{c}\text { Median }=8 \\
(I Q R=5-11)\end{array}$ \\
\hline
\end{tabular}

* number of baseline variables that the hazard ratios were adjusted for in Cox regression analyses 
Table 2. Pooled hazard ratio estimates for all-cause and specific-cause mortality risk associated with underweight, overweight and obese BMI categories compared to normal-weight status

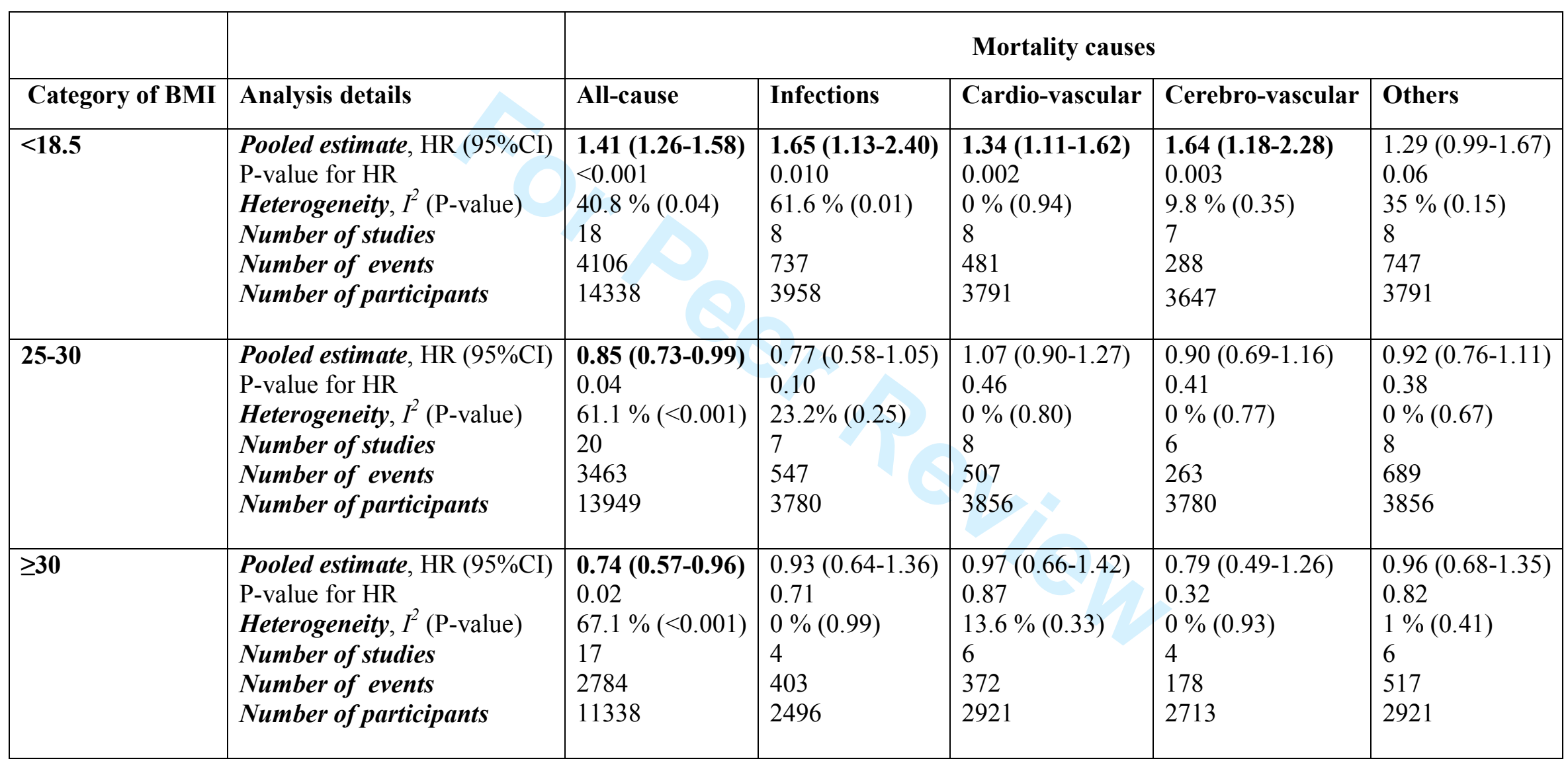

Bolded HR values: $\mathrm{p}<0.05$ 
Table 3. Adjusted hazard ratios of each study by BMI categories compared to normal-weight residents for all-cause and specific cause mortality.

\begin{tabular}{|c|c|c|c|c|c|c|c|}
\hline $\begin{array}{c}\text { First author, } \\
\text { publication } \\
\text { year }\end{array}$ & $\begin{array}{c}\text { BMI } \\
\text { category }\end{array}$ & $\begin{array}{c}\text { All-cause } \\
\mathrm{HR}(95 \% \mathrm{CI})\end{array}$ & $\begin{array}{c}\text { Infections } \\
\mathrm{HR}(95 \% \mathrm{CI})\end{array}$ & $\begin{array}{l}\text { Cardio-vascular } \\
\text { HR }(95 \% \mathrm{CI})\end{array}$ & $\begin{array}{c}\text { Cerebro-vascular } \\
\text { HR }(95 \% \mathrm{CI})\end{array}$ & $\begin{array}{c}\text { Others } \\
\text { HR }(95 \% \mathrm{CI})\end{array}$ & Adjustments \\
\hline \multirow{3}{*}{$\underset{32}{\text { Abe, } 2011}$} & Underweight & $1.04(0.69-1.56)$ & $0.83(0.47-1.46)$ & $1.69(0.18-16.10)$ & $1.34(0.32-5.65)$ & $1.47(0.71-3.05)$ & \multirow{3}{*}{$\begin{array}{c}\text { Age, gender, } \\
\text { dementia, stroke, } \\
\text { cancer, infectious } \\
\text { diseases, CVD, } \\
\text { COPD, changes in } \\
\text { BMI at LOCF. }\end{array}$} \\
\hline & Overweight & $1.83(0.83-4.06)$ & $1.37(0.39-4.75)$ & $6.99(0.35-140.17)$ & No cases & $2.40(0.71-8.10)$ & \\
\hline & Obese & Not computed $^{\mathrm{a}}$ & Not computed $^{\mathrm{a}}$ & Not computed $^{\mathrm{a}}$ & Not computed $^{\mathrm{a}}$ & Not computed $^{\mathrm{a}}$ & \\
\hline \multirow{3}{*}{$\underset{33}{\text { Allard, } 2004}$} & Underweight & $0.80(0.50-1.27)$ & Not available & Not available & Not available & Not available & \multirow{3}{*}{$\begin{array}{c}\text { Age, gender, } \\
\text { infectious diseases, } \\
\text { disability }\end{array}$} \\
\hline & Overweight & $0.75(0.49-1.11)$ & Not available & Not available & Not available & Not available & \\
\hline & Obese & $0.57(0.28-1.18)$ & Not available & Not available & Not available & Not available & \\
\hline \multirow{3}{*}{$\underset{34}{\text { Beck, }} 2008$} & Underweight & $1.81(1.17-2.80)$ & Not available & Not available & Not available & Not available & \multirow{3}{*}{$\begin{array}{c}\text { Age, gender, } \\
\text { dementia, stroke, } \\
\text { cancer, infectious } \\
\text { diseases, diabetes, } \\
\text { hypertension, CVD, } \\
\text { COPD, disability, } \\
\text { changes in BMI at } \\
\text { LOCF }\end{array}$} \\
\hline & Overweight & $0.62(0.33-1.16)$ & Not available & Not available & Not available & Not available & \\
\hline & Obese & $0.72(0.34-1.54)$ & Not available & Not available & Not available & Not available & \\
\hline \multirow{3}{*}{$\underset{35}{\text { Cereda, }} 2011$} & Underweight & $1.29(0.97-1.71)$ & $1.09(0.55-2.17)$ & $1.49(1.03-2.15)$ & $1.31(0.68-1.55)$ & $1.03(0.53-1.97)$ & \multirow{3}{*}{$\begin{array}{l}\text { Age, gender, } \\
\text { dementia, stroke, } \\
\text { cancer, infectious } \\
\text { diseases, diabetes, } \\
\text { hypertension, CVD, } \\
\text { COPD, disability }\end{array}$} \\
\hline & Overweight & $0.97(0.76-1.24)$ & $0.44(0.21-0.93)$ & $1.16(0.85-1.58)$ & $1.02(0.58-1.79)$ & $0.75(0.43-1.32)$ & \\
\hline & Obese & $0.66(0.44-0.98)$ & $0.93(0.42-2.08)$ & $0.57(0.32-1.04)$ & $0.71(0.28-1.79)$ & $0.56(0.24-1.31)$ & \\
\hline \multirow{3}{*}{$\underset{36}{\text { Chan, } 2010}$} & Underweight & $2.47(1.11-5.48)$ & $3.73(0.82-16.97)$ & $0.45(0.23-8.87)$ & \multirow{3}{*}{$\begin{array}{c}\text { Only } 1 \text { death due } \\
\text { to stroke in the } \\
\text { cohort }\end{array}$} & $2.16(0.76-6.08)$ & \multirow{3}{*}{$\begin{array}{l}\text { Age, gender, } \\
\text { disability }\end{array}$} \\
\hline & Overweight & $6.13(0.84-71.42)$ & No events & $0.98(0.40-2.37)$ & & $0.86(0.34-2.16)$ & \\
\hline & Obese & Not computed ${ }^{\mathrm{a}}$ & Not computed $^{\mathrm{a}}$ & Not computed $^{\mathrm{a}}$ & & Not computed ${ }^{\mathrm{a}}$ & \\
\hline \multirow{3}{*}{$\underset{37}{\text { Hsu, } 2013}$} & Underweight & $1.37(0.91-2.07)$ & $5.96(1.89-18.80)$ & $1.31(0.63-2.73)$ & $3.32(1.20-9.19)$ & $0.47(0.16-1.36)$ & \multirow{3}{*}{$\begin{array}{c}\text { Age, gender, } \\
\text { dementia, stroke, } \\
\text { cancer, disability }\end{array}$} \\
\hline & Overweight & $0.87(0.53-1.43)$ & $1.07(0.21-5.60)$ & $1.26(0.52-3.03)$ & $0.76(0.16-3.62)$ & $1.07(0.51-2.25)$ & \\
\hline & Obese & $0.88(0.36-2.19)$ & No events & $1.56(0.35-6.86)$ & No events & $0.42(0.06-3.19)$ & \\
\hline \multirow{2}{*}{$\underset{38}{\text { Kaiser, } 2010}$} & Underweight & Not computed $^{\text {a }}$ & Not available & Not available & Not available & Not available & \multirow{2}{*}{$\begin{array}{c}\text { Age, gender, } \\
\text { dementia, disability }\end{array}$} \\
\hline & Overweight & $0.75(0.36-1.57)$ & Not available & Not available & Not available & Not available & \\
\hline
\end{tabular}




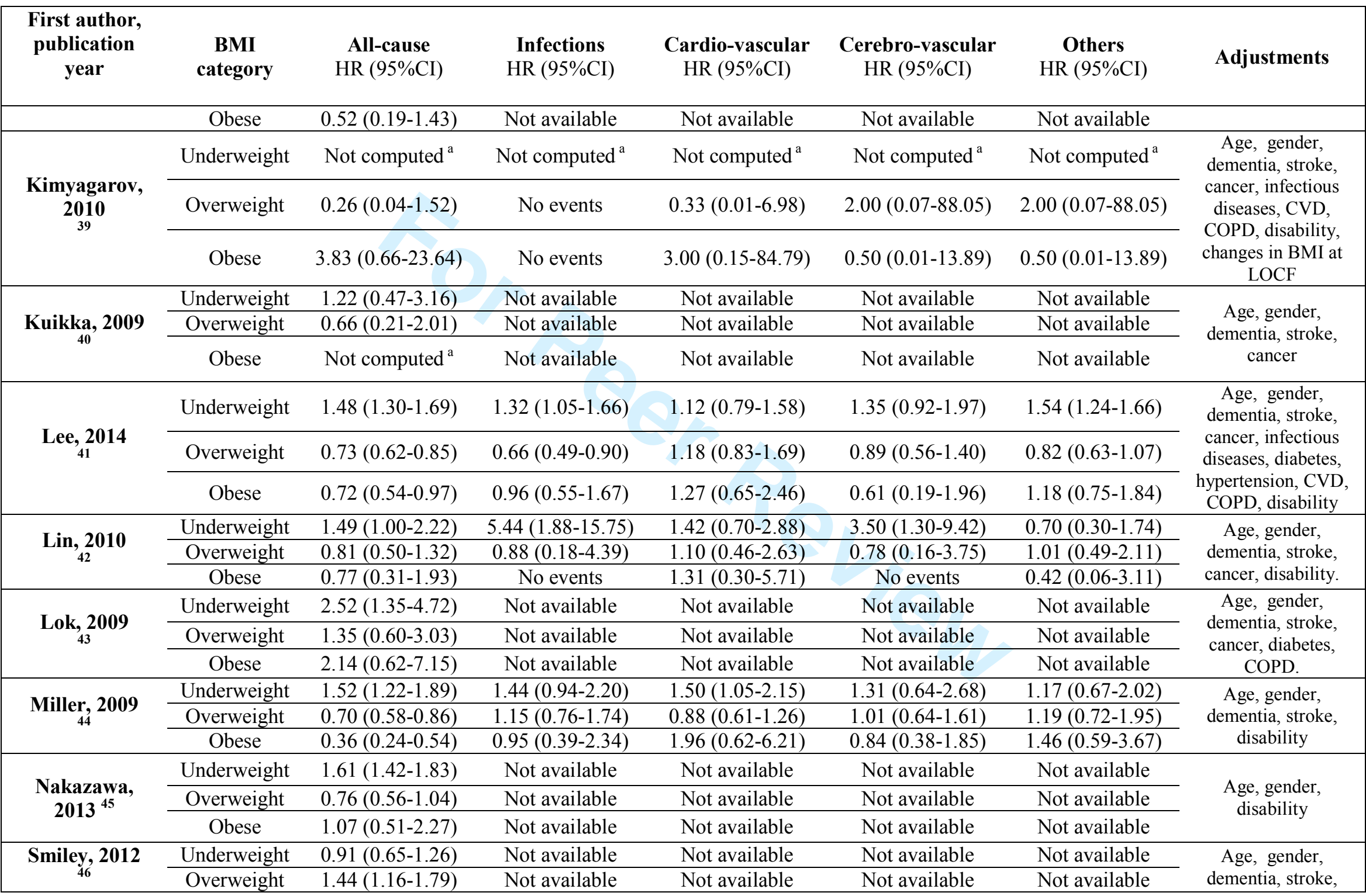




\begin{tabular}{|c|c|c|c|c|c|c|c|}
\hline $\begin{array}{c}\text { First author, } \\
\text { publication } \\
\text { year }\end{array}$ & $\begin{array}{c}\text { BMI } \\
\text { category }\end{array}$ & $\begin{array}{c}\text { All-cause } \\
\text { HR }(95 \% \mathrm{CI})\end{array}$ & $\begin{array}{l}\text { Infections } \\
\text { HR }(95 \% \mathrm{CI})\end{array}$ & $\begin{array}{c}\text { Cardio-vascular } \\
\text { HR }(95 \% \mathrm{CI})\end{array}$ & $\begin{array}{c}\text { Cerebro-vascular } \\
\text { HR }(95 \% \mathrm{CI})\end{array}$ & $\begin{array}{c}\text { Others } \\
\text { HR }(95 \% \mathrm{CI})\end{array}$ & Adjustments \\
\hline & Obese & $1.35(1.02-1.79)$ & Not available & Not available & Not available & Not available & $\begin{array}{l}\text { cancer, diabetes, } \\
\text { hypertension, } \\
\text { COPD. }\end{array}$ \\
\hline \multirow{2}{*}{$\begin{array}{c}\text { Sund-Levander, } \\
2007 \\
47\end{array}$} & Underweight & $1.78(0.92-3.43)$ & $1.81(0.52-6.34)$ & $1.29(0.45-3.76)$ & $1.80(0.51-6.40)$ & $2.33(0.76-7.11)$ & \multirow{2}{*}{$\begin{array}{c}\text { Age, gender, } \\
\text { dementia, stroke, } \\
\text { cancer, infectious } \\
\text { diseases, diabetes, } \\
\text { hypertension, CVD, } \\
\text { COPD, disability }\end{array}$} \\
\hline & Overweight & $0.88(0.59-1.31)$ & $0.63(0.25-1.55)$ & $0.89(0.50-1.57)$ & $0.47(0.19-1.14)$ & $1.01(0.46-2.20)$ & \\
\hline \multirow[b]{3}{*}{$\underset{48}{\operatorname{Torma}}, 2013$} & Underweight & $0.80(0.23-2.83)$ & Not available & Not available & Not available & Not available & \multirow{3}{*}{$\begin{array}{l}\text { Age, gender, } \\
\text { dementia, stroke, } \\
\text { cancer, infectious } \\
\text { diseases, diabetes, } \\
\text { hypertension, CVD, } \\
\text { COPD, disability }\end{array}$} \\
\hline & Overweight & $1.12(0.36-3.49)$ & Not available & Not available & Not available & Not available & \\
\hline & Obese & $0.56(0.14-2.20)$ & Not available & Not available & Not available & Not available & \\
\hline \multirow{3}{*}{$\underset{50}{\text { Veronese, }} 2013$} & Underweight & $1.97(0.89-4.38)$ & Not available & Not available & Not available & Not available & \multirow{3}{*}{$\begin{array}{c}\text { Age, gender, } \\
\text { dementia, cancer, } \\
\text { diabetes, } \\
\text { hypertension, } \\
\text { disability }\end{array}$} \\
\hline & Overweight & $0.93(0.61-1.42)$ & Not available & Not available & Not available & Not available & \\
\hline & Obese & $0.58(0.30-1.10)$ & Not available & Not available & Not available & Not available & \\
\hline \multirow{3}{*}{$\underset{51}{\text { Volpato. }} 2004$} & Underweight & $1.21(0.76-1.92)$ & Not available & Not available & Not available & Not available & \multirow{3}{*}{$\begin{array}{l}\text { Age, gender, } \\
\text { dementia, stroke, } \\
\text { cancer, infectious } \\
\text { diseases, diabetes, } \\
\text { hypertension, CVD, } \\
\text { COPD, disability }\end{array}$} \\
\hline & Overweight & $0.83(0.56-1.22)$ & Not available & Not available & Not available & Not available & \\
\hline & Obese & $1.09(0.63-1.89)$ & Not available & Not available & Not available & Not available & \\
\hline
\end{tabular}

Abbreviations: BMI, body mass index; CVD, cardiovascular diseases; COPD, chronic obstructive pulmonary disease; LOCF, last observation carrying forward; HR (95\%CI), hazard ratio and 95\% confidence interval

${ }^{\mathrm{a}}$ Could not be computed due to limited number of residents $(<15)$ in the BMI category. 
Table 4. All-cause mortality risk for strata of different moderators

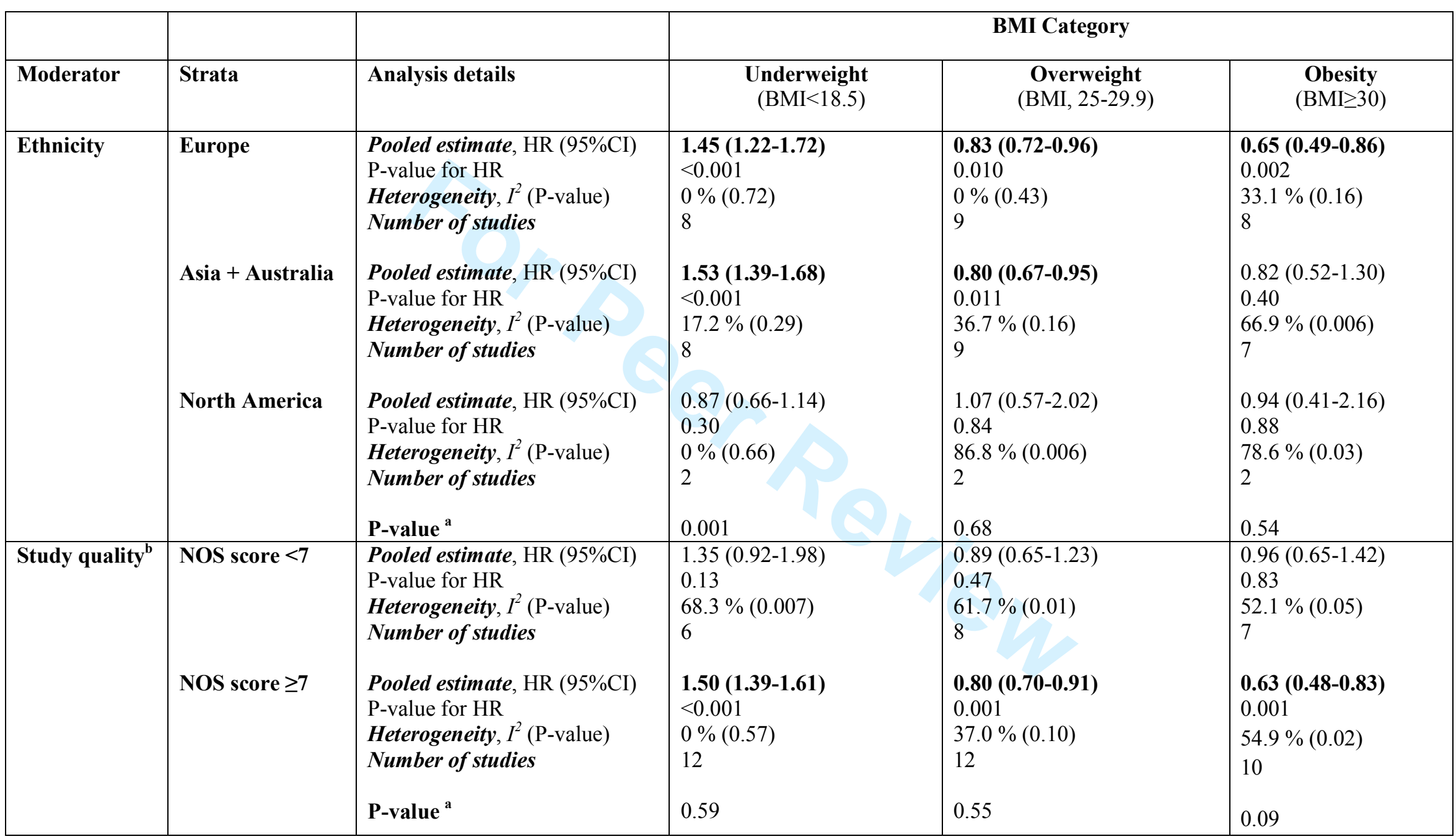




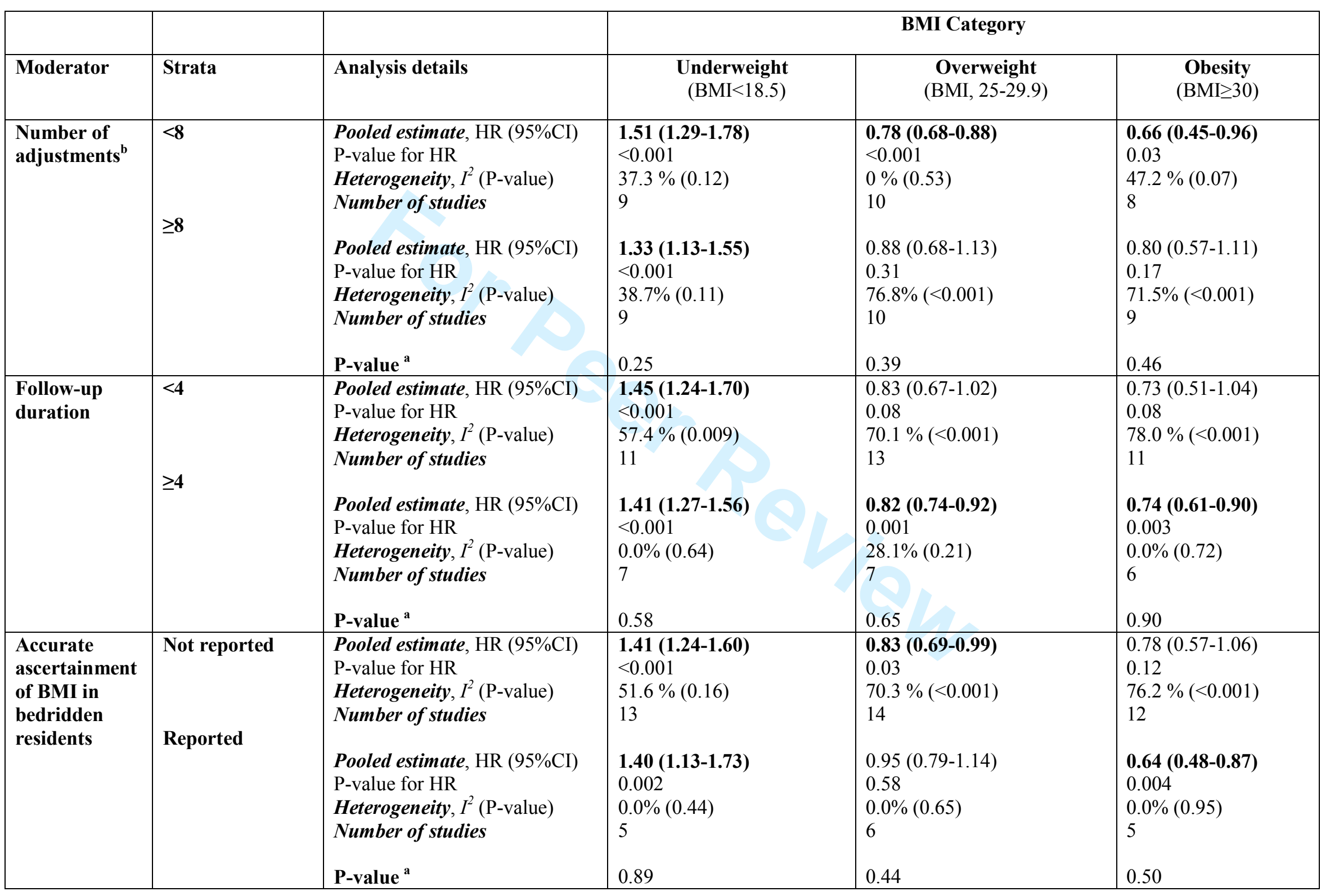


Bolded HR values: $\mathrm{p}<0.05$

Abbreviations: NOS, Newcastle-Ottawa Scale

${ }^{a}$ The P-value for the t-test between the two statistical analysis strata according to meta-regression procedure.

${ }^{\mathrm{b}}$ Stratification was performed by median NOS score and number of adjustments as appropriate. 
Pooled estimates (RRs) and $95 \% \mathrm{CI}$ for mortality risk associated with underweight, overweight and obesity compared to normal weight status (Plot A, all-cause mortality; Plot $B$, mortality due to infectious disease; Plot C, mortality due to cardiovascular causes; Plot D, mortality due to cerebrovascular causes; Plot E, mortality due to other causes). $327 \times 163 \mathrm{~mm}(300 \times 300 \mathrm{DPI})$ 


\title{
SUPPLEMENTARY DATA
}

\section{Inverse Relationship Between Body Mass Index and Mortality in Older Nursing-Home Residents: A Meta-analysis of 19,538 Elderly Subjects}

Running title: BMI and mortality in nursing home

\begin{abstract}
Nicola Veronese ${ }^{1}$, Emanuele Cereda $^{2}$, Marco Solmi $^{3}$, Susan A. Fowler ${ }^{4}$, Enzo Manzato ${ }^{1,5}$, Stefania Maggi ${ }^{5}$, Peter Manu ${ }^{6-9}$, Eiko Abe ${ }^{10}$, Kunihiko Hayashi ${ }^{10}$, Johane Allard ${ }^{11,12}$, Bianca Arendt ${ }^{11}$, Anne Marie Beck ${ }^{13}$, Mark Chan ${ }^{14}$, Yeo Jing Ping Audrey ${ }^{14}$, Wen-Yuan Lin ${ }^{15}$, Hua-Shui Hsu ${ }^{15}$, Cheng-Chieh Lin ${ }^{15}$, Rebecca Diekmann $^{16}$, Simca Kimyagarov ${ }^{17}$, Michelle Miller ${ }^{18}$, Ian Cameron ${ }^{19}$, Kaisu H. Pitkälä ${ }^{20}$, Jenny Lee ${ }^{21}$, Jean Woo $^{21}$, Kazutoshi Nakamura ${ }^{22}$, Dawn Smiley ${ }^{23}$, Guillermo Umpierrez ${ }^{23}$, Mariangela Rondanelli ${ }^{24}$, Martha Sund-Levander ${ }^{25}$, Luzia Valentini ${ }^{26}$, Karin Schindler ${ }^{27}$, Johanna Törmä ${ }^{28}$, Stefano Volpato ${ }^{29}$, Giovanni Zuliani $^{29}$, Moses Wong ${ }^{30}$, Kris Lok $^{30}$, John M. Kane ${ }^{6-9}$, Giuseppe Sergi ${ }^{1}$, Christoph U. Correll ${ }^{6-9}$
\end{abstract}

\section{Affiliations:}

${ }^{1}$ Department of Medicine- DIMED, Geriatrics Section, University of Padova, Italy.

${ }^{2}$ Nutrition and Dietetics Service, Fondazione IRCCS Policlinico San Matteo, Pavia, Italy.

${ }^{3}$ Department of Neurosciences, University of Padova, Padova, Italy.

${ }^{4}$ Becker Medical Library, Washington University in St. Louis, MO, USA.

${ }^{5}$ National Research Council, Institute of Neuroscience, Padova, Italy.

${ }^{6}$ The Zucker Hillside Hospital, Psychiatry Research, North Shore - Long Island Jewish Health System, Glen Oaks, New York, USA.

${ }^{7}$ Hofstra North Shore LIJ School of Medicine, Hempstead, New York, USA.

${ }^{8}$ The Feinstein Institute for Medical Research, Manhasset, New York, USA.

${ }^{9}$ Albert Einstein College of Medicine, Bronx, New York, USA.

${ }^{10}$ Gunma University Graduate School of Health Sciences, Maebashi, Gunma, Japan.

${ }^{11}$ Toronto General Hospital, University Health Network, Toronto, Canada.

${ }^{12}$ Department of Medicine, University of Toronto, Toronto, Canada.

${ }^{13}$ Research Unit for Nutrition (EFFECT), Herlev University Hospital, Herlev, Denmark.

${ }^{14}$ Department of Geriatric Medicine, Tan Tock Seng Hospital, Jalan Tan Tock Seng, Singapore. IASO Journals 
${ }^{15}$ Department of Family Medicine, China Medical University Hospital, Taichung, Taiwan and School of Medicine, China Medical University, Taichung, Taiwan.

${ }^{16}$ Institute for Biomedicine of Aging, Friedrich-Alexander-Universität Erlangen-Nürnberg, Nürnberg, Germany.

${ }^{17}$ The Gilad Geriatric Center, Ramat-Gan, Israel.

${ }^{18}$ Nutrition and Dietetics, Flinders University, Adelaide, Australia.

${ }^{19}$ Rehabilitation Studies Unit, University of Sydney, Australia.

${ }^{20}$ Unit of Primary Health Care, Helsinki University Central Hospital, Department of General Practice, Helsinki, Finland.

${ }^{21}$ The S. H. Ho Center for Gerontology and Geriatrics, The Chinese University of Hong Kong, Hong Kong SAR, China; Department of Medicine and Therapeutics, The Chinese University of Hong Kong, Hong Kong SAR, China.

${ }^{22}$ Division of Preventive Medicine, Niigata University Graduate School of Medical and Dental Sciences, Niigata, Japan.

${ }^{23}$ Division of Endocrinology and Metabolism, Department of Medicine, Emory University School of Medicine, Atlanta, GA, USA.

${ }^{24}$ Department of Public Health, Experimental and Forensic Medicine, Section of Human Nutrition, Endocrinology and Nutrition Unit, University of Pavia, Pavia, Italy.

${ }^{25}$ Faculty of Health Sciences, University of Linköping, Linköping, Sweden.

${ }^{26}$ Section of Dietetics, Department of Agriculture and Food Sciences, University of Applied Sciences, Neubrandenburg, Germany.

${ }^{27}$ Division of Endocrinology and Metabolism, Department of Internal Medicine III, Medical University Vienna, Vienna, Austria.

${ }^{28}$ Department of Public Health and Caring Sciences, Clinical Nutrition and Metabolism, Uppsala Science Park, Uppsala, Sweden.

${ }^{29}$ Department of Medical Sciences, University of Ferrara, Ferrara, Italy.

${ }^{30}$ Department of Medicine \& Therapeutics, The Chinese University of Hong Kong. 


\section{Correspondence to:}

Christoph U. Correll, MD, Department of Psychiatry, The Zucker Hillside Hospital, 75-59 $263^{\text {rd }}$ Street, Glen Oaks, NY 11004. Email: ccorrell@lij.edu, phone: (718) 470-4812, fax (718) 343-1659 
Table S1. Search strategies

PubMed, Filters activated: English, 113 results found 05/31/2014

("Nursing Homes"[Mesh] OR "Nursing Homes" OR "Nursing Home" OR “Intermediate Care Facilities" OR "Intermediate Care Facility" OR "Skilled Nursing Facilities" OR "Skilled Nursing Facility" OR "Extended Care Facilities" OR “Extended Care Facility” OR “convalescence home” OR “convalescence hospital”) AND ("Body Mass Index"[Mesh] OR "Obesity"[Mesh] OR "Overweight"[Mesh] OR "Thinness"[Mesh] OR "Emaciation"[Mesh] OR "Cachexia"[Mesh] OR "Body Mass Index" OR “Quetelet Index” OR “Quetelet's Index" OR "Quetelets Index" OR "BMI” OR "Obesity" OR “Obesities” OR “obese” OR “adipose tissue hyperplasia” OR “adipositas” OR “adiposity” OR “excess body weight” OR “obesitas” OR “overweight” OR “weight insufficiency" OR "leanness" OR “Underweight” OR "Emaciation" OR "Emaciated” OR "Cachexia" OR “cachectic”) AND ("Mortality"[Mesh] OR "mortality" [Subheading] OR "Mortality” OR "Mortalities" OR “Case Fatality Rate" OR “Case Fatality Rates" OR "Death Rate” OR "Death Rates" OR "survival") NOT ("Controlled Clinical Trial"[Publication Type] OR "Randomized Controlled Trial" [Publication Type] "Clinical Trial" [Publication Type] OR "Clinical Trial, Phase IV" [Publication Type] OR "Clinical Trial, Phase III" [Publication Type] OR "Clinical Trial, Phase II" [Publication Type] OR "Clinical Trial, Phase I" [Publication Type])

Embase, 172 results found 05/31/2014

'nursing home'/exp OR 'Nursing Homes' OR 'Nursing Home' OR ‘Intermediate Care Facilities' OR 'Intermediate Care Facility’ OR ‘Skilled Nursing Facilities’ OR ‘Skilled Nursing Facility’ OR ‘Extended Care Facilities' OR 'Extended Care Facility' OR ‘convalescence home' OR ‘convalescence hospital' AND ('body mass'/exp OR 'obesity'/exp OR 'underweight'/exp OR 'cachexia'/exp OR 'Body Mass Index' OR 'Quetelet Index' OR ‘Quetelets Index’ OR ‘BMI’ OR ‘body ban mass' OR ‘Obesity’ OR ‘Obesities' OR 'obese' OR ‘adipose tissue hyperplasia' OR 'adipositas' OR 'adiposity' OR 'excess body weight' OR 'fat overload syndrome' OR ‘obesitas' OR ‘overweight' OR ‘weight insufficiency' OR ‘leanness' OR 'Underweight' OR 'Emaciation' OR 'Emaciated' OR 'Cachexia' OR 'cachectic') AND ('mortality'/exp OR 'Mortality' OR ‘Mortalities' OR ‘Case Fatality Rate' OR ‘Case Fatality Rates' OR ‘Death Rate' OR ‘Death Rates' OR 'survival') NOT ('controlled clinical trial'/it OR 'randomized controlled trial'/it OR 'controlled clinical trial'/exp OR 'randomized controlled trial'/exp OR 'clinical trial'/exp) 
Table S2. Excluded eligible studies due to lack of mortality data in standardized BMI groups (Authors did not answer).

1. Breschi M, Capriati A, Falcini F, Ferrucci L. [Fattori nutrizionali di rischio negli anziani istituzionalizzati]. Riv Ital Nutr Par Ent. 1995; 13: 122-29.

2. Enomoto R, Kikutani T, Suzuki A, Inaba S. [Relationship between eating dysfunction and life span and mortality in institutionalized elderly people]. Nihon Ronen Igakkai Zasshi. 2007; 44:95-101.

3. Kiesswetter E, Schrader E, Diekmann R, Sieber CC, Volkert D. Dysphagia and cognitive impairment increase the risk of malnutrition in nursing home residents new data from the Nutrition-Day in European nursing homes. Clinical Nutrition. 2011; 6: S31-S32.

4. Landi F, Russo A, Danese P, Liperoti R, Barillaro C, Bernabei R, Onder G. Anemia status, hemoglobin concentration, and mortality in nursing home older residents. J Am Med Dir Assoc. 2007;8: 322-327.

5. Landi F, Liperoti R, Fusco D, Mastropaolo S, Quattrociocchi D, Proia A, et al.. Sarcopenia and mortality among older nursing home residents. J Am Med Dir Assoc. 2012;13:121-126

6. Lin SJ, Hwang SJ, Liu CY, Lin HR. The relationship between nutritional status and physical function, admission frequency, length of hospital stay, and mortality in old people living in long-term care facilities. J Nurs Res. 2012; 20:110-121.

7. Pilz S, Meinitzer A, Tomaschitz A, Kienreich K, Dobnig H, Schwarz M, et al. Associations of homoarginine with bone metabolism and density, muscle strength and mortality: cross-sectional and prospective data from 506 female nursing home patients. Osteoporos Int. 2013;24:377-381.

8. Grabowski DC, Campbell CM, Ellis JE. Obesity and mortality in elderly nursing home residents. J Gerontol A Biol Sci Med Sci. 2005; 60:1184-1189.

9. Hossain M, Ooi WL, Lipsitz LA. Intra-individual postural blood pressure variability and stroke in elderly nursing home residents. J Clin Epidemiol. 2001; 54:488-494.

10. Kiely DK, Flacker JM. Resident characteristics associated with mortality in long-term care nursing homes: is there a gender difference? J Am Med Dir Assoc. 2000;1: 8-13

11. Kiely DK, Flacker JM. Common and gender specific factors associated with one-year mortality in nursing home residents. J Am Med Dir Assoc. 2002;3: 302-309.

12. Saka B, Ozkaya H, Karisik E, Dogan H, Horasan Z, Cesur K, et al. Malnutrition in nursing home and its association with sarcopenia and mortality. European Geriatric Medicine. 2013; 4: S125

13. Sullivan DH, Morley JE, Johnson LE, Barber A, Olson JS, Stevens MR, et al. The GAIN (Geriatric Anorexia Nutrition) registry: the impact of appetite and weight on mortality in a long-term care population. J Nutr Health Aging. 2002; 6: 275-81

14. Sullivan DH, Johnson LE, Bopp MM, Roberson PK. Prognostic significance of monthly weight fluctuations among older nursing home residents. J Gerontol A Biol Sci Med Sci. 2004;59:633-639.

15. Tsai AC, Ku PY, Tsai JD. Population-specific Mini Nutritional Assessment can improve mortality- 
16. Tsai AC, Lai MC, Chang TL. Mid-arm and calf circumferences (MAC and CC) are better than body mass index (BMI) in predicting health status and mortality risk in institutionalized elderly Taiwanese. Arch Gerontol Geriatr. 2012 ; 54:443-447. 
Table S3. Methodological quality of cohort studies included in the meta-analysis*

\begin{tabular}{|c|c|c|c|c|c|c|c|c|c|}
\hline $\begin{array}{l}\text { First author, } \\
\text { publication year }\end{array}$ & $\begin{array}{c}\text { Representativeness } \\
\text { of the exposed } \\
\text { cohort }\end{array}$ & $\begin{array}{l}\text { Selection of } \\
\text { the } \\
\text { unexposed } \\
\text { cohort }\end{array}$ & $\begin{array}{l}\text { Ascertainment } \\
\text { of exposure }\end{array}$ & $\begin{array}{l}\text { Outcome of } \\
\text { interest } \\
\text { not present } \\
\text { at start of } \\
\text { study } \\
\dagger \dagger\end{array}$ & $\begin{array}{l}\text { Control for } \\
\text { important } \\
\text { factor or } \\
\text { additional } \\
\text { factor }^{\dagger \dagger \dagger}\end{array}$ & $\begin{array}{l}\text { Assessment } \\
\text { of outcome }\end{array}$ & $\begin{array}{l}\text { Follow-up } \\
\text { long enough } \\
\text { for outcomes } \\
\text { to occur }{ }^{\dagger \dagger \dagger \dagger}\end{array}$ & $\begin{array}{l}\text { Adequacy of } \\
\text { follow-up } \\
\text { of cohorts }\end{array}$ & $\begin{array}{c}\text { Total } \\
\text { quality } \\
\text { scores }\end{array}$ \\
\hline Abe, $2011^{32}$ & * & $*$ & - & $*$ & $* *$ & $*$ & $*$ & $*$ & 8 \\
\hline Allard, $2004^{33}$ & $*$ & $*$ & - & - & - & $*$ & - & $*$ & 4 \\
\hline Beck, $2008^{34}$ & $*$ & $*$ & - & $*$ & - & $*$ & - & $*$ & 5 \\
\hline Cereda, $2011^{35}$ & $*$ & * & $*$ & $*$ & $* *$ & $*$ & $*$ & $*$ & 9 \\
\hline Chan, $2010^{36}$ & $*$ & * & $*$ & $*$ & $* *$ & $*$ & - & $*$ & 8 \\
\hline Hsu, $2013^{37}$ & * & * & $*$ & - & $* *$ & * & $*$ & * & 8 \\
\hline Kaiser, $2010^{38}$ & $*$ & $*$ & $*$ & - & - & $*$ & - & $*$ & 5 \\
\hline Kimyagarov, $2010^{39}$ & * & $*$ & - & - & - & * & - & * & 3 \\
\hline Kuikka, $2009{ }^{40}$ & $*$ & $*$ & - & $*$ & - & $*$ & - & $*$ & 5 \\
\hline Lee, $2014^{41}$ & * & $*$ & - & * & $* *$ & * & * & * & 8 \\
\hline Lin, $2010^{42}$ & * & * & - & * & $* *$ & * & * & $*$ & 8 \\
\hline Lok, $2009^{43}$ & $*$ & $*$ & - & - & - & $*$ & - & $*$ & 4 \\
\hline Miller, $2009^{44}$ & $*$ & $*$ & - & * & $* *$ & $*$ & - & $*$ & 7 \\
\hline Nakazawa, $2013^{45}$ & $*$ & $*$ & - & $*$ & $* *$ & $*$ & - & $*$ & 7 \\
\hline Smiley, $2012^{46}$ & - & $*$ & - & - & - & $*$ & - & $*$ & 3 \\
\hline Sund-Levander, $2007^{47}$ & - & $*$ & - & $*$ & $* *$ & $*$ & $*$ & - & 6 \\
\hline Torma, $2013^{48}$ & $*$ & $*$ & $*$ & $*$ & $*$ & $*$ & - & $*$ & 7 \\
\hline Valentini, $2009^{49}$ & $*$ & $*$ & - & $*$ & $* *$ & $*$ & - & $*$ & 7 \\
\hline Veronese, $2013^{50}$ & $*$ & $*$ & $*$ & $*$ & $* *$ & $*$ & $*$ & $*$ & 9 \\
\hline Volpato, $2004^{51}$ & $*$ & $*$ & - & $*$ & $* *$ & $*$ & - & $*$ & 7 \\
\hline
\end{tabular}

Original studies were analyzed in the quality assessment.

* A study could be awarded a maximum of one star for each item except for the item Control for important factor or additional factor. The definition/explanation of 5 each column of the Newcastle-Ottawa Scale is available at http://www.ohri.ca/programs/clinical_epidemiology/oxford.htm.

$\dagger$ For this index, one star was given if in Method section was indicated if weight and height were taken in bedridden patients.

$37 \dagger$ Being outcome of interest mortality, we took as outcome of interest for assessment of quality if the presence of cognitive impairment, disability or frailty was assessed.

$39+\dagger \dagger$ A maximum of 2 stars could be awarded for this item. Studies that controlled for at least three confounders or including disability or frailty indexes received one 40 star, whereas studies that controlled their survival analysis for more than 4 confounders received an additional star.

$41+\dagger \dagger$ A cohort study with a mean/median follow-up time $\geq 5$ y was assigned one star. 


\section{FIGURE LEGENDS}

Figure S1. PRISMA flow-chart.

Figure S2. Relationship between mortality risk and baseline body mass index levels.

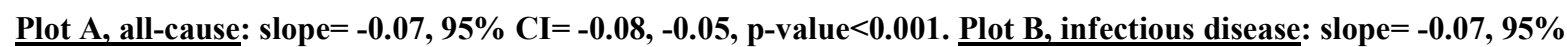

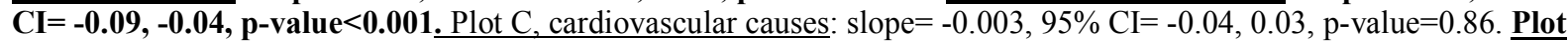
$\underline{D}$, cerebrovascular causes: slope $=\mathbf{- 0 . 0 4 , 9 5 \% ~ C I = - 0 . 0 2 , - 0 . 0 7 , ~ p - v a l u e ~}=0.02$.

Plot $\mathrm{E}$, other causes: slope $=0.01,95 \% \mathrm{CI}=-0.04,0.002$; $\mathrm{p}$-value $=0.08$.

Significant associations $(\mathrm{p}<0.05)$ were typed in bold.

The gray lines indicate the $95 \%$ CIs around the regression line.. 


\section{Page 49 of 88}

2

3

4

5

6

7

8

9

10

11

12

13

14

15

16

17

18

19

20

21

22

23

24

25

26

27

28

29

30

31

32

33

34

35

36

37

38

39

40

41

42

43

44

45

46

47

48

49

50

51

52

53

54

55

56

57

58

59

60

PRISMA flow-chart. $202 \times 190 \mathrm{~mm}(300 \times 300 \mathrm{DPI})$ 

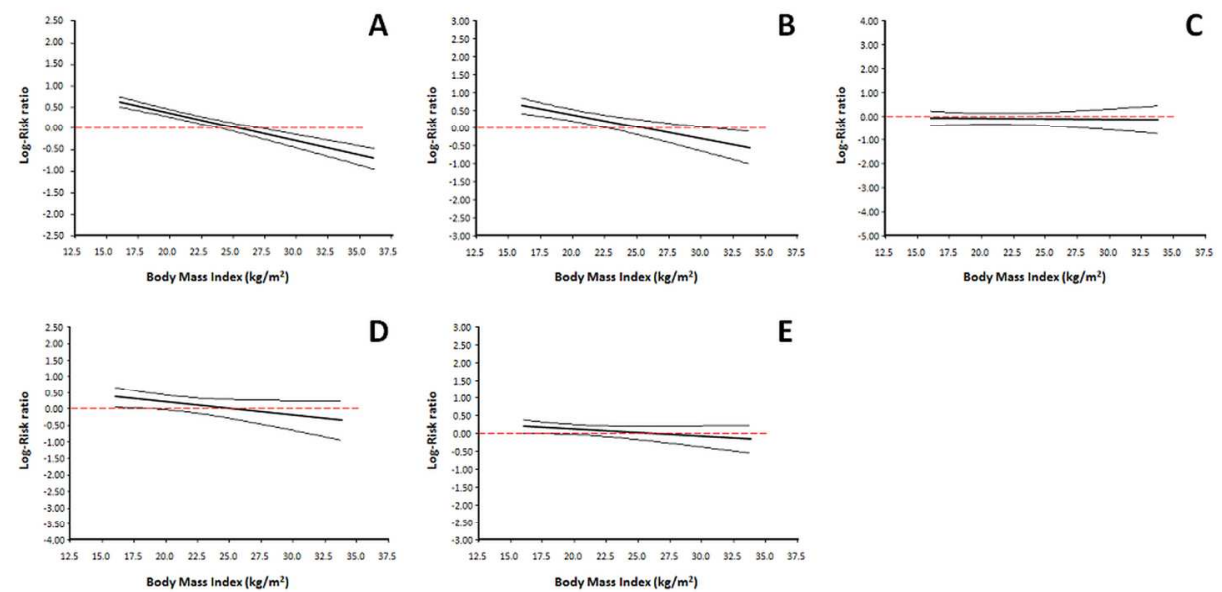

Relationship between mortality risk and baseline body mass index levels.

Plot $A$, all-cause: slope $=-0.07,95 \% C I=-0.08,-0.05, p$-value $<0.001$. Plot $B$, infectious disease: slope $=-$ $0.07,95 \% \mathrm{CI}=-0.09,-0.04, \mathrm{p}$-value $<0.001$. Plot $\mathrm{C}$, cardiovascular causes: slope $=-0.003,95 \% \mathrm{CI}=-0.04$, $0.03, \mathrm{p}$-value $=0.86$. Plot $\mathrm{D}$, cerebrovascular causes: slope $=-0.04,95 \% \mathrm{CI}=-0.02,-0.07, \mathrm{p}-\mathrm{value}=0.02$. Plot $\mathrm{E}$, other causes: slope $=0.01,95 \% \mathrm{CI}=-0.04,0.002 ; \mathrm{p}$-value $=0.08$.

Significant associations $(p<0.05)$ were typed in bold. The gray lines indicate the $95 \%$ CIs around the regression line. $231 \times 117 \mathrm{~mm}$ (300 x 300 DPI) 


\section{Please wait...}

If this message is not eventually replaced by the proper contents of the document, your PDF viewer may not be able to display this type of document.

You can upgrade to the latest version of Adobe Reader for Windows®, Mac, or Linux® by visiting http://www.adobe.com/go/reader_download.

For more assistance with Adobe Reader visit http://www.adobe.com/go/acrreader.

Windows is either a registered trademark or a trademark of Microsoft Corporation in the United States and/or other countries. Mac is a trademark of Apple Inc., registered in the United States and other countries. Linux is the registered trademark of Linus Torvalds in the U.S. and other countries. 


\section{Please wait...}

If this message is not eventually replaced by the proper contents of the document, your PDF viewer may not be able to display this type of document.

You can upgrade to the latest version of Adobe Reader for Windows®, Mac, or Linux® by visiting http://www.adobe.com/go/reader_download.

For more assistance with Adobe Reader visit http://www.adobe.com/go/acrreader.

Windows is either a registered trademark or a trademark of Microsoft Corporation in the United States and/or other countries. Mac is a trademark of Apple Inc., registered in the United States and other countries. Linux is the registered trademark of Linus Torvalds in the U.S. and other countries. 


\section{Please wait...}

If this message is not eventually replaced by the proper contents of the document, your PDF viewer may not be able to display this type of document.

You can upgrade to the latest version of Adobe Reader for Windows®, Mac, or Linux® by visiting http://www.adobe.com/go/reader_download.

For more assistance with Adobe Reader visit http://www.adobe.com/go/acrreader.

Windows is either a registered trademark or a trademark of Microsoft Corporation in the United States and/or other countries. Mac is a trademark of Apple Inc., registered in the United States and other countries. Linux is the registered trademark of Linus Torvalds in the U.S. and other countries. 


\section{Please wait...}

If this message is not eventually replaced by the proper contents of the document, your PDF viewer may not be able to display this type of document.

You can upgrade to the latest version of Adobe Reader for Windows®, Mac, or Linux® by visiting http://www.adobe.com/go/reader_download.

For more assistance with Adobe Reader visit http://www.adobe.com/go/acrreader.

Windows is either a registered trademark or a trademark of Microsoft Corporation in the United States and/or other countries. Mac is a trademark of Apple Inc., registered in the United States and other countries. Linux is the registered trademark of Linus Torvalds in the U.S. and other countries. 


\section{Please wait...}

If this message is not eventually replaced by the proper contents of the document, your PDF viewer may not be able to display this type of document.

You can upgrade to the latest version of Adobe Reader for Windows®, Mac, or Linux® by visiting http://www.adobe.com/go/reader_download.

For more assistance with Adobe Reader visit http://www.adobe.com/go/acrreader.

Windows is either a registered trademark or a trademark of Microsoft Corporation in the United States and/or other countries. Mac is a trademark of Apple Inc., registered in the United States and other countries. Linux is the registered trademark of Linus Torvalds in the U.S. and other countries. 


\section{Please wait...}

If this message is not eventually replaced by the proper contents of the document, your PDF viewer may not be able to display this type of document.

You can upgrade to the latest version of Adobe Reader for Windows®, Mac, or Linux® by visiting http://www.adobe.com/go/reader_download.

For more assistance with Adobe Reader visit http://www.adobe.com/go/acrreader.

Windows is either a registered trademark or a trademark of Microsoft Corporation in the United States and/or other countries. Mac is a trademark of Apple Inc., registered in the United States and other countries. Linux is the registered trademark of Linus Torvalds in the U.S. and other countries. 
To view the full contents of this document, you need a later version of the PDF viewer. You can upgrade to the latest version of Adobe Reader from www.adobe.com/products/acrobat/readstep2.html

For further support, go to www.adobe.com/support/products/acrreader.html 


\section{Please wait...}

If this message is not eventually replaced by the proper contents of the document, your PDF viewer may not be able to display this type of document.

You can upgrade to the latest version of Adobe Reader for Windows®, Mac, or Linux® by visiting http://www.adobe.com/go/reader_download.

For more assistance with Adobe Reader visit http://www.adobe.com/go/acrreader.

Windows is either a registered trademark or a trademark of Microsoft Corporation in the United States and/or other countries. Mac is a trademark of Apple Inc., registered in the United States and other countries. Linux is the registered trademark of Linus Torvalds in the U.S. and other countries. 


\section{Please wait...}

If this message is not eventually replaced by the proper contents of the document, your PDF viewer may not be able to display this type of document.

You can upgrade to the latest version of Adobe Reader for Windows®, Mac, or Linux® by visiting http://www.adobe.com/go/reader_download.

For more assistance with Adobe Reader visit http://www.adobe.com/go/acrreader.

Windows is either a registered trademark or a trademark of Microsoft Corporation in the United States and/or other countries. Mac is a trademark of Apple Inc., registered in the United States and other countries. Linux is the registered trademark of Linus Torvalds in the U.S. and other countries. 


\section{Please wait...}

If this message is not eventually replaced by the proper contents of the document, your PDF viewer may not be able to display this type of document.

You can upgrade to the latest version of Adobe Reader for Windows®, Mac, or Linux® by visiting http://www.adobe.com/go/reader_download.

For more assistance with Adobe Reader visit http://www.adobe.com/go/acrreader.

Windows is either a registered trademark or a trademark of Microsoft Corporation in the United States and/or other countries. Mac is a trademark of Apple Inc., registered in the United States and other countries. Linux is the registered trademark of Linus Torvalds in the U.S. and other countries. 


\section{Please wait...}

If this message is not eventually replaced by the proper contents of the document, your PDF viewer may not be able to display this type of document.

You can upgrade to the latest version of Adobe Reader for Windows®, Mac, or Linux® by visiting http://www.adobe.com/go/reader_download.

For more assistance with Adobe Reader visit http://www.adobe.com/go/acrreader.

Windows is either a registered trademark or a trademark of Microsoft Corporation in the United States and/or other countries. Mac is a trademark of Apple Inc., registered in the United States and other countries. Linux is the registered trademark of Linus Torvalds in the U.S. and other countries. 


\section{Please wait...}

If this message is not eventually replaced by the proper contents of the document, your PDF viewer may not be able to display this type of document.

You can upgrade to the latest version of Adobe Reader for Windows®, Mac, or Linux® by visiting http://www.adobe.com/go/reader_download.

For more assistance with Adobe Reader visit http://www.adobe.com/go/acrreader.

Windows is either a registered trademark or a trademark of Microsoft Corporation in the United States and/or other countries. Mac is a trademark of Apple Inc., registered in the United States and other countries. Linux is the registered trademark of Linus Torvalds in the U.S. and other countries. 
To view the full contents of this document, you need a later version of the PDF viewer. You can upgrade to the latest version of Adobe Reader from www.adobe.com/products/acrobat/readstep2.html

For further support, go to www.adobe.com/support/products/acrreader.html 


\section{Please wait...}

If this message is not eventually replaced by the proper contents of the document, your PDF viewer may not be able to display this type of document.

You can upgrade to the latest version of Adobe Reader for Windows®, Mac, or Linux® by visiting http://www.adobe.com/go/reader_download.

For more assistance with Adobe Reader visit http://www.adobe.com/go/acrreader.

Windows is either a registered trademark or a trademark of Microsoft Corporation in the United States and/or other countries. Mac is a trademark of Apple Inc., registered in the United States and other countries. Linux is the registered trademark of Linus Torvalds in the U.S. and other countries. 


\section{Please wait...}

If this message is not eventually replaced by the proper contents of the document, your PDF viewer may not be able to display this type of document.

You can upgrade to the latest version of Adobe Reader for Windows®, Mac, or Linux® by visiting http://www.adobe.com/go/reader_download.

For more assistance with Adobe Reader visit http://www.adobe.com/go/acrreader.

Windows is either a registered trademark or a trademark of Microsoft Corporation in the United States and/or other countries. Mac is a trademark of Apple Inc., registered in the United States and other countries. Linux is the registered trademark of Linus Torvalds in the U.S. and other countries. 


\section{Please wait...}

If this message is not eventually replaced by the proper contents of the document, your PDF viewer may not be able to display this type of document.

You can upgrade to the latest version of Adobe Reader for Windows®, Mac, or Linux® by visiting http://www.adobe.com/go/reader_download.

For more assistance with Adobe Reader visit http://www.adobe.com/go/acrreader.

Windows is either a registered trademark or a trademark of Microsoft Corporation in the United States and/or other countries. Mac is a trademark of Apple Inc., registered in the United States and other countries. Linux is the registered trademark of Linus Torvalds in the U.S. and other countries. 


\section{Please wait...}

If this message is not eventually replaced by the proper contents of the document, your PDF viewer may not be able to display this type of document.

You can upgrade to the latest version of Adobe Reader for Windows®, Mac, or Linux® by visiting http://www.adobe.com/go/reader_download.

For more assistance with Adobe Reader visit http://www.adobe.com/go/acrreader.

Windows is either a registered trademark or a trademark of Microsoft Corporation in the United States and/or other countries. Mac is a trademark of Apple Inc., registered in the United States and other countries. Linux is the registered trademark of Linus Torvalds in the U.S. and other countries. 


\section{Please wait...}

If this message is not eventually replaced by the proper contents of the document, your PDF viewer may not be able to display this type of document.

You can upgrade to the latest version of Adobe Reader for Windows®, Mac, or Linux® by visiting http://www.adobe.com/go/reader_download.

For more assistance with Adobe Reader visit http://www.adobe.com/go/acrreader.

Windows is either a registered trademark or a trademark of Microsoft Corporation in the United States and/or other countries. Mac is a trademark of Apple Inc., registered in the United States and other countries. Linux is the registered trademark of Linus Torvalds in the U.S. and other countries. 


\section{Please wait...}

If this message is not eventually replaced by the proper contents of the document, your PDF viewer may not be able to display this type of document.

You can upgrade to the latest version of Adobe Reader for Windows®, Mac, or Linux® by visiting http://www.adobe.com/go/reader_download.

For more assistance with Adobe Reader visit http://www.adobe.com/go/acrreader.

Windows is either a registered trademark or a trademark of Microsoft Corporation in the United States and/or other countries. Mac is a trademark of Apple Inc., registered in the United States and other countries. Linux is the registered trademark of Linus Torvalds in the U.S. and other countries. 


\section{Please wait...}

If this message is not eventually replaced by the proper contents of the document, your PDF viewer may not be able to display this type of document.

You can upgrade to the latest version of Adobe Reader for Windows®, Mac, or Linux® by visiting http://www.adobe.com/go/reader_download.

For more assistance with Adobe Reader visit http://www.adobe.com/go/acrreader.

Windows is either a registered trademark or a trademark of Microsoft Corporation in the United States and/or other countries. Mac is a trademark of Apple Inc., registered in the United States and other countries. Linux is the registered trademark of Linus Torvalds in the U.S. and other countries. 


\section{Please wait...}

If this message is not eventually replaced by the proper contents of the document, your PDF viewer may not be able to display this type of document.

You can upgrade to the latest version of Adobe Reader for Windows®, Mac, or Linux® by visiting http://www.adobe.com/go/reader_download.

For more assistance with Adobe Reader visit http://www.adobe.com/go/acrreader.

Windows is either a registered trademark or a trademark of Microsoft Corporation in the United States and/or other countries. Mac is a trademark of Apple Inc., registered in the United States and other countries. Linux is the registered trademark of Linus Torvalds in the U.S. and other countries. 


\section{Please wait...}

If this message is not eventually replaced by the proper contents of the document, your PDF viewer may not be able to display this type of document.

You can upgrade to the latest version of Adobe Reader for Windows®, Mac, or Linux® by visiting http://www.adobe.com/go/reader_download.

For more assistance with Adobe Reader visit http://www.adobe.com/go/acrreader.

Windows is either a registered trademark or a trademark of Microsoft Corporation in the United States and/or other countries. Mac is a trademark of Apple Inc., registered in the United States and other countries. Linux is the registered trademark of Linus Torvalds in the U.S. and other countries. 


\section{Please wait...}

If this message is not eventually replaced by the proper contents of the document, your PDF viewer may not be able to display this type of document.

You can upgrade to the latest version of Adobe Reader for Windows®, Mac, or Linux® by visiting http://www.adobe.com/go/reader_download.

For more assistance with Adobe Reader visit http://www.adobe.com/go/acrreader.

Windows is either a registered trademark or a trademark of Microsoft Corporation in the United States and/or other countries. Mac is a trademark of Apple Inc., registered in the United States and other countries. Linux is the registered trademark of Linus Torvalds in the U.S. and other countries. 


\section{Please wait...}

If this message is not eventually replaced by the proper contents of the document, your PDF viewer may not be able to display this type of document.

You can upgrade to the latest version of Adobe Reader for Windows®, Mac, or Linux® by visiting http://www.adobe.com/go/reader_download.

For more assistance with Adobe Reader visit http://www.adobe.com/go/acrreader.

Windows is either a registered trademark or a trademark of Microsoft Corporation in the United States and/or other countries. Mac is a trademark of Apple Inc., registered in the United States and other countries. Linux is the registered trademark of Linus Torvalds in the U.S. and other countries. 


\section{Please wait...}

If this message is not eventually replaced by the proper contents of the document, your PDF viewer may not be able to display this type of document.

You can upgrade to the latest version of Adobe Reader for Windows®, Mac, or Linux® by visiting http://www.adobe.com/go/reader_download.

For more assistance with Adobe Reader visit http://www.adobe.com/go/acrreader.

Windows is either a registered trademark or a trademark of Microsoft Corporation in the United States and/or other countries. Mac is a trademark of Apple Inc., registered in the United States and other countries. Linux is the registered trademark of Linus Torvalds in the U.S. and other countries. 


\section{Please wait...}

If this message is not eventually replaced by the proper contents of the document, your PDF viewer may not be able to display this type of document.

You can upgrade to the latest version of Adobe Reader for Windows®, Mac, or Linux® by visiting http://www.adobe.com/go/reader_download.

For more assistance with Adobe Reader visit http://www.adobe.com/go/acrreader.

Windows is either a registered trademark or a trademark of Microsoft Corporation in the United States and/or other countries. Mac is a trademark of Apple Inc., registered in the United States and other countries. Linux is the registered trademark of Linus Torvalds in the U.S. and other countries. 


\section{Please wait...}

If this message is not eventually replaced by the proper contents of the document, your PDF viewer may not be able to display this type of document.

You can upgrade to the latest version of Adobe Reader for Windows®, Mac, or Linux® by visiting http://www.adobe.com/go/reader_download.

For more assistance with Adobe Reader visit http://www.adobe.com/go/acrreader.

Windows is either a registered trademark or a trademark of Microsoft Corporation in the United States and/or other countries. Mac is a trademark of Apple Inc., registered in the United States and other countries. Linux is the registered trademark of Linus Torvalds in the U.S. and other countries. 


\section{Please wait...}

If this message is not eventually replaced by the proper contents of the document, your PDF viewer may not be able to display this type of document.

You can upgrade to the latest version of Adobe Reader for Windows®, Mac, or Linux® by visiting http://www.adobe.com/go/reader_download.

For more assistance with Adobe Reader visit http://www.adobe.com/go/acrreader.

Windows is either a registered trademark or a trademark of Microsoft Corporation in the United States and/or other countries. Mac is a trademark of Apple Inc., registered in the United States and other countries. Linux is the registered trademark of Linus Torvalds in the U.S. and other countries. 


\section{Please wait...}

If this message is not eventually replaced by the proper contents of the document, your PDF viewer may not be able to display this type of document.

You can upgrade to the latest version of Adobe Reader for Windows®, Mac, or Linux® by visiting http://www.adobe.com/go/reader_download.

For more assistance with Adobe Reader visit http://www.adobe.com/go/acrreader.

Windows is either a registered trademark or a trademark of Microsoft Corporation in the United States and/or other countries. Mac is a trademark of Apple Inc., registered in the United States and other countries. Linux is the registered trademark of Linus Torvalds in the U.S. and other countries. 


\section{Please wait...}

If this message is not eventually replaced by the proper contents of the document, your PDF viewer may not be able to display this type of document.

You can upgrade to the latest version of Adobe Reader for Windows®, Mac, or Linux® by visiting http://www.adobe.com/go/reader_download.

For more assistance with Adobe Reader visit http://www.adobe.com/go/acrreader.

Windows is either a registered trademark or a trademark of Microsoft Corporation in the United States and/or other countries. Mac is a trademark of Apple Inc., registered in the United States and other countries. Linux is the registered trademark of Linus Torvalds in the U.S. and other countries. 


\section{Please wait...}

If this message is not eventually replaced by the proper contents of the document, your PDF viewer may not be able to display this type of document.

You can upgrade to the latest version of Adobe Reader for Windows®, Mac, or Linux® by visiting http://www.adobe.com/go/reader_download.

For more assistance with Adobe Reader visit http://www.adobe.com/go/acrreader.

Windows is either a registered trademark or a trademark of Microsoft Corporation in the United States and/or other countries. Mac is a trademark of Apple Inc., registered in the United States and other countries. Linux is the registered trademark of Linus Torvalds in the U.S. and other countries. 


\section{Please wait...}

If this message is not eventually replaced by the proper contents of the document, your PDF viewer may not be able to display this type of document.

You can upgrade to the latest version of Adobe Reader for Windows®, Mac, or Linux® by visiting http://www.adobe.com/go/reader_download.

For more assistance with Adobe Reader visit http://www.adobe.com/go/acrreader.

Windows is either a registered trademark or a trademark of Microsoft Corporation in the United States and/or other countries. Mac is a trademark of Apple Inc., registered in the United States and other countries. Linux is the registered trademark of Linus Torvalds in the U.S. and other countries. 


\section{Please wait...}

If this message is not eventually replaced by the proper contents of the document, your PDF viewer may not be able to display this type of document.

You can upgrade to the latest version of Adobe Reader for Windows®, Mac, or Linux® by visiting http://www.adobe.com/go/reader_download.

For more assistance with Adobe Reader visit http://www.adobe.com/go/acrreader.

Windows is either a registered trademark or a trademark of Microsoft Corporation in the United States and/or other countries. Mac is a trademark of Apple Inc., registered in the United States and other countries. Linux is the registered trademark of Linus Torvalds in the U.S. and other countries. 


\section{Please wait...}

If this message is not eventually replaced by the proper contents of the document, your PDF viewer may not be able to display this type of document.

You can upgrade to the latest version of Adobe Reader for Windows®, Mac, or Linux® by visiting http://www.adobe.com/go/reader_download.

For more assistance with Adobe Reader visit http://www.adobe.com/go/acrreader.

Windows is either a registered trademark or a trademark of Microsoft Corporation in the United States and/or other countries. Mac is a trademark of Apple Inc., registered in the United States and other countries. Linux is the registered trademark of Linus Torvalds in the U.S. and other countries. 


\section{Please wait...}

If this message is not eventually replaced by the proper contents of the document, your PDF viewer may not be able to display this type of document.

You can upgrade to the latest version of Adobe Reader for Windows®, Mac, or Linux® by visiting http://www.adobe.com/go/reader_download.

For more assistance with Adobe Reader visit http://www.adobe.com/go/acrreader.

Windows is either a registered trademark or a trademark of Microsoft Corporation in the United States and/or other countries. Mac is a trademark of Apple Inc., registered in the United States and other countries. Linux is the registered trademark of Linus Torvalds in the U.S. and other countries. 
To view the full contents of this document, you need a later version of the PDF viewer. You can upgrade to the latest version of Adobe Reader from www.adobe.com/products/acrobat/readstep2.html

For further support, go to www.adobe.com/support/products/acrreader.html 


\section{Please wait...}

If this message is not eventually replaced by the proper contents of the document, your PDF viewer may not be able to display this type of document.

You can upgrade to the latest version of Adobe Reader for Windows®, Mac, or Linux® by visiting http://www.adobe.com/go/reader_download.

For more assistance with Adobe Reader visit http://www.adobe.com/go/acrreader.

Windows is either a registered trademark or a trademark of Microsoft Corporation in the United States and/or other countries. Mac is a trademark of Apple Inc., registered in the United States and other countries. Linux is the registered trademark of Linus Torvalds in the U.S. and other countries. 


\section{Please wait...}

If this message is not eventually replaced by the proper contents of the document, your PDF viewer may not be able to display this type of document.

You can upgrade to the latest version of Adobe Reader for Windows®, Mac, or Linux® by visiting http://www.adobe.com/products/acrobat/readstep2.html.

For more assistance with Adobe Reader visit http://www.adobe.com/support/products/ acrreader.html.

Windows is either a registered trademark or a trademark of Microsoft Corporation in the United States and/or other countries. Mac is a trademark of Apple Inc., registered in the United States and other countries. Linux is the registered trademark of Linus Torvalds in the U.S. and other countries. 


\section{Please wait...}

If this message is not eventually replaced by the proper contents of the document, your PDF viewer may not be able to display this type of document.

You can upgrade to the latest version of Adobe Reader for Windows®, Mac, or Linux® by visiting http://www.adobe.com/go/reader_download.

For more assistance with Adobe Reader visit http://www.adobe.com/go/acrreader.

Windows is either a registered trademark or a trademark of Microsoft Corporation in the United States and/or other countries. Mac is a trademark of Apple Inc., registered in the United States and other countries. Linux is the registered trademark of Linus Torvalds in the U.S. and other countries. 